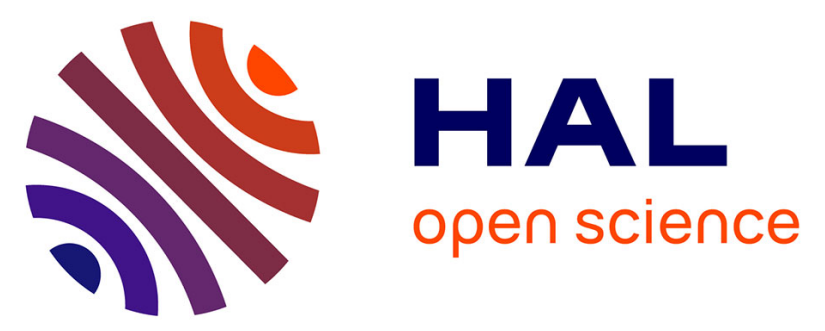

\title{
Catalytic ozonation with $\gamma$-Al2O3 to enhance the degradation of refractory organics in water
}

Jullian Vittenet, Aboussaoud Wael, Mendret Julie, Jean-Stephane Pic, Hubert Jean-Stephane, Nicolas Lesage, Karine Faucher, Marie-Hélène Manero, Thibault-Starzyk Frederic, Hervé Leclerc, et al.

\section{To cite this version:}

Jullian Vittenet, Aboussaoud Wael, Mendret Julie, Jean-Stephane Pic, Hubert Jean-Stephane, et al.. Catalytic ozonation with $\gamma$-Al2O3 to enhance the degradation of refractory organics in water. Applied Catalysis A : General, 2015, 504, pp.519-532. 10.1016/j.apcata.2014.10.037 . hal-01079847

\section{HAL Id: hal-01079847 https://hal.science/hal-01079847}

Submitted on 6 Nov 2018

HAL is a multi-disciplinary open access archive for the deposit and dissemination of scientific research documents, whether they are published or not. The documents may come from teaching and research institutions in France or abroad, or from public or private research centers.
L'archive ouverte pluridisciplinaire HAL, est destinée au dépôt et à la diffusion de documents scientifiques de niveau recherche, publiés ou non, émanant des établissements d'enseignement et de recherche français ou étrangers, des laboratoires publics ou privés. 


\section{Open Archive Toulouse Archive Ouverte (OATAO)}

OATAO is an open access repository that collects the work of some Toulouse researchers and makes it freely available over the web where possible.

This is an author's version published in: http://oatao.univ-toulouse.fr/20587

Official URL: $\underline{\text { https://doi.org/10.1016/j.apcata.2014.10.037 }}$

\section{To cite this version:}

Vittenet, Jullian and Aboussaoud, Wael and Mendret, Julie and Pic, Jean-Stéphane and Debellefontaine, Hubert and Lesage, Nicolas and Faucher, Karine and Manero, MarieHélène and Thibault-Starzyk, Frédéric and Leclerc, Hervé and Galarneau, Anne and Brosillon, Stéphan Catalytic ozonation with $\gamma$-Al2O3 to enhance the degradation of refractory organics in water. (2015) Applied Catalysis A General, 504. 519-532. ISSN 0926-860X

Any correspondance concerning this service should be sent to the repository administrator: tech-oatao@listes-diff.inp-toulouse.fr 


\title{
Catalytic ozonation with $\gamma-\mathrm{Al}_{2} \mathrm{O}_{3}$ to enhance the degradation of refractory organics in water
}

\author{
Jullian Vittenet ${ }^{\mathrm{a}, \mathrm{b}}$, Wael Aboussaoud ${ }^{\mathrm{c}, \mathrm{d}}$, Julie Mendret ${ }^{\mathrm{a}}$, Jean-Stéphane Pic ${ }^{\mathrm{c}}$, \\ Hubert Debellefontaine $^{c}$, Nicolas Lesage ${ }^{e}$, Karine Faucher ${ }^{e}$, Marie-Hélène Manero $^{d}$, \\ Frédéric Thibault-Starzyk ${ }^{\mathrm{f}}$, Hervé Leclerc ${ }^{\mathrm{f}}$, Anne Galarneau ${ }^{\mathrm{b}, *}$, Stéphan Brosillon ${ }^{\mathrm{a}}$ \\ a IEM (Institut Européen des Membranes), UMR 5635 CNRS-ENSCM-UM2, Université Montpellier 2, Place E. Bataillon, 34095 Montpellier, France \\ b Institut Charles Gerhardt Montpellier, UMR 5253 CNRS/UM2/ENSCM/UM1-ENSCM, 8 rue de l'Ecole Normale, 34296 Montpellier Cedex 5, France \\ c Université de Toulouse, LISBP, UMR INSA/CNRS 5504 E UMR INSA/INRA 792, 135 avenue de Rangueil, 31077 Toulouse Cedex 4, France \\ ' Université de Toulouse, INPT, UPS, Laboratoire de Génie Chimique, 4 allée Emile Monso, 31432 Toulouse Cedex 4, France \\ e TOTAL, PERL, RN117 BP 47, F-64170 Lacq, France \\ f Laboratoire Catalyse et Spectrochimie, ENSICAEN Université de Caen CNRS, 6 Boulevard Maréchal Juin, 14050 Caen Cedex, France
}

Keywords:

Catalytic ozonation

Wastewater treatment

$\mathrm{Al}_{2} \mathrm{O}_{3}$

Phenol

Advanced oxidation process
A B S T R A C T

Nowadays, heterogeneous catalytic ozonation appears as a promising way to treat industrial wastewaters containing refractory pollutants, which resist to biological treatments. Several oxides and minerals have been used and their behavior is subject to controversy with particularly the role of Lewis acid sites and/or basic sites and the effect of salts. In this study, millimetric mesoporous $\gamma-\mathrm{Al}_{2} \mathrm{O}_{3}$ particles suitable for industrial processes were used for enhancing the ozonation efficiency of petrochemical effluents without $\mathrm{pH}$ adjustment. A phenol (2,4-dimethylphenol (2,4-DMP)) was first chosen as petrochemical refractory molecule to evaluate the influence of alumina in ozonation. Single ozonation and ozonation in presence of $\gamma-\mathrm{Al}_{2} \mathrm{O}_{3}$ led to the disappearance of 2,4-DMP in $25 \mathrm{~min}$ and a decrease in pH from 4.5 to 2.5. No adsorption of 2,4-DMP occurred on $\gamma-\mathrm{Al}_{2} \mathrm{O}_{3}$. Adding $\gamma-\mathrm{Al}_{2} \mathrm{O}_{3}$ in the process resulted in an increase of the 2,4-DMP oxidation level. Indeed, the total organic carbon (TOC) removal was $14 \%$ for a single ozonation and $46 \%$ for ozonation with $\gamma-\mathrm{Al}_{2} \mathrm{O}_{3}$. Similarly, chemical oxygen demand (COD) removal increases from 35 to $75 \%$, respectively. Various oxidized by-products were produced during the degradation of 2,4-DMP, but after 5 h ozonation $90 \%$ of organic by-products were acetic acid $>$ formic acid $\gg$ oxalic acid. Some of the carboxylic acids were adsorbed on $\gamma-\mathrm{Al}_{2} \mathrm{O}_{3}$. The use of radical scavengers (tert-butanol) highlighted the involvement of hydroxyl radicals during catalytic ozonation with $\gamma-\mathrm{Al}_{2} \mathrm{O}_{3}$ in contrary to single ozonation, which mainly involved direct ozone reaction. $\gamma-\mathrm{Al}_{2} \mathrm{O}_{3}$ is an amphoteric solid with Lewis acid $\mathrm{AlOH}\left(\mathrm{H}^{+}\right)$sites and basicAl-OH sites. After ozonation the amount of basic sites decreased due to carboxylates adsorption, while the Lewis acid sites remained constant as evidenced by FTIR. Several ozonation runs with $\gamma-\mathrm{Al}_{2} \mathrm{O}_{3}$ reported a progressive decrease of its catalytic activity due to the cumulative sorption of carboxylates on the basic sites. After $80 \mathrm{~h}$ of ozonation, a calcination at $550{ }^{\circ} \mathrm{C}$ allowed to recover allAl-OH basic sites and the initial activity of $\gamma-\mathrm{Al}_{2} \mathrm{O}_{3}$. A synthetic petrochemical effluent containing various petrochemicals (phenol, acetic acid, naphtenic acid, pyrene, naphtalene) was then treated with $\gamma-\mathrm{Al}_{2} \mathrm{O}_{3}$ with and without $\mathrm{NaCl}$. Sodium ions prevented carboxylates adsorption on $\gamma-\mathrm{Al}_{2} \mathrm{O}_{3}$ leading to a higher efficiency of $\gamma-\mathrm{Al}_{2} \mathrm{O}_{3}$ in presence of $\mathrm{NaCl}$ and allowed to decrease the toxicity of the petrochemical effluent.

\footnotetext{
* Corresponding author. Tel.: +3346716 3468 .

E-mail address: anne.galarneau@enscm.fr (A. Galarneau).
}

\section{Introduction}

In recent years, many efforts on the advanced oxidation processes (AOPs) development have been done for wastewater treatment especially in industries to treat organic compounds resistant to biological treatments [1]. Among the AOPs, processes based on ozone appear as promising technologies for the removal 
of refractory compounds [2-7]. In aqueous media, $\mathrm{O}_{3}$ can react directly with organic compounds and/or indirectly when $\mathrm{O}_{3}$ is decomposed into free radicals, which have higher oxidizing rate than $\mathrm{O}_{3}$ itself $[2-4,8]$. Consequently, favoring this second route allows to reach higher levels of toxic pollutant mineralization. The indirect reaction in single ozonation is influenced by the $\mathrm{pH}$ of the solution (high $\mathrm{pH}$ ), the solution composition and the temperature, but it is limited to a certain extend of mineralization $[3,8]$. In this context, some studies have focused on heterogeneous catalytic ozonation in aqueous media since the early 2000s, due to the enhancement of the production of hydroxyl radicals with materials such as activated carbons, zeolites, oxides $\left(\mathrm{CeO}_{2}, \mathrm{TiO}_{2}, \mathrm{MgO}, \mathrm{Al}_{2} \mathrm{O}_{3}, \mathrm{MnO}_{2}, \mathrm{Fe}_{2} \mathrm{O}_{3}, \mathrm{Co}_{3} \mathrm{O}_{4}\right.$, $\left.\mathrm{NiO}, \mathrm{CuO}, \mathrm{ZnO}, \mathrm{ZrO}_{2}, \ldots\right)$ and the subsequent ozone economy [4,8-17]. However, all of these materials have never been studied in identical conditions, so it is difficult to compare their efficiency. An excellent review by Nawrocki and Kassprzyk-Hordern in 2010 reported the different materials and conditions used in catalytic ozonation in this last decade [8]. They report that the following order in term of better heterogeneous catalysts appears in certain conditions (ozonation of dinitrobenzene at $\mathrm{pH} 3$ ): $\mathrm{Fe}_{2} \mathrm{O}_{3}>\mathrm{CO}_{3} \mathrm{O}_{4}>\mathrm{MoO}_{3}>\mathrm{CuO} \sim \mathrm{NiO}>\mathrm{Al}_{2} \mathrm{O}_{3}>\mathrm{TiO}_{2}>\mathrm{Cr}_{2} \mathrm{O}_{3} \sim \mathrm{MnO}_{2} \sim \mathrm{O}_{3}$ which seems to follow the basicity strength of the oxides $(\mathrm{Mn}>\mathrm{Fe}>\mathrm{Co}>\mathrm{Ni}>\mathrm{Cu}>\mathrm{Zn})$ except for $\mathrm{MnO}_{2}$. However, in some other studies $\mathrm{MnO}_{2}$ was demonstrated as the more active catalyst, but leaching of some cations have been also observed, as well as for $\mathrm{CuO}$. Some of these oxides need to be supported for industrial processes to avoid fine particles and the leaching of metal has to be avoided. In this review was also highlighted the wide controversy of mechanisms proposed in literature responsible for the increase of ozone activity in the presence of materials and especially the role of Lewis acid sites and/or basic sites, which remained a subject of debate. Catalytic ozonation appears as a highly suitable process for petrochemical wastewater treatments as ozone is especially active for refractory molecules of this industry such as aromatic molecules substituted with electron donor groups as alkyl-benzene (toluene, xylene, ethylbenzene), phenols (alkylphenols) and polyaromatic hydrocarbons (naphtalene, phenantrene, anthracene, ...).

It was previously shown that the catalytic activity of activated carbons in ozonation decreased after several runs by the loss of their basic sites and no regeneration was possible [5-7]. Inorganic catalysts should be preferred. Zeolites and oxides in ozonation for wastewater treatment provide many advantages: no chemicals to add, simplicity of use and high pollutant removal efficiency [15]. Concerning the zeolites in ozonation process for organic compounds removal, it seems that the reaction mechanisms are zeolite structures dependent [18]. Some studies revealed the adsorption capacity of pollutant and/or ozone into the micropores of zeolites, especially in ZSM-5 structure type, which does not confer any radical pathway but serve as reservoir of ozone and adsorbents of organic compounds [19-21]. Besides, it was also demonstrated that zeolites could catalyze ozone decomposition and enhance the generation of hydroxyl radicals $\left(\mathrm{HO}^{\bullet}\right)$ [11]. Indeed, it was recently reported that basic zeolites as LTA zeolite can enhance radicals generation by combining two pathways: the production of hydroxide ions during the cation-exchange of Na-zeolite with the protons of the solution and by the interaction of ozone with some hydroxyl groups present as defects in the material [18]. However, a decrease of the LTA catalytic activity was observed for a second run of phenol compounds ozonation due in part to the irreversibility of the cation-exchange [18]. Other porous materials especially $\gamma-\mathrm{Al}_{2} \mathrm{O}_{3}$ have been identified to generate free radicals from the interaction between their hydroxyl groups and ozone [20,22,23]. A study suggested that $\gamma-\mathrm{Al}_{2} \mathrm{O}_{3}$ combined to $\mathrm{O}_{3}$ allowed an enhancement of $\mathrm{HO}^{\bullet}$ radical via ${ }^{\bullet} \mathrm{O}_{2}{ }^{-}$and/or ${ }^{\bullet} \mathrm{O}_{3}{ }^{-}$radicals, resulting in a faster carboxylic acids removal than single ozonation [22]. Recently, Ikhlaq et al. [20] confirmed this hypothesis and pointed out also that $\mathrm{HO}^{\bullet}$ radicals can combine with themselves to produce $\mathrm{H}_{2} \mathrm{O}_{2}$, depending on the $\mathrm{pH}$ of the solution. This was demonstrated after $\mathrm{pH}$ adjustment for $\mathrm{pH}$ higher than $\mathrm{pH}=6.2$. Another catalytic reaction mechanism with aluminum oxides was also proposed due to the ir capacity to adsorb ozone and to decompose it into free radicals by interacting with the hydroxyl groups of the materials $[16,24]$. Moreover, the catalytic effect of $\gamma-\mathrm{Al}_{2} \mathrm{O}_{3}$ was preserved after several ozonation runs, indicating no poisoning of the active sites for ozone decomposition [16]. However, the increase of the pollutant removal efficiency by heterogeneous ozonation with $\gamma-\mathrm{Al}_{2} \mathrm{O}_{3}$ was also attributed to the adsorption of ozonation by-products. On the one hand, pharmaceutical pollutant removal experiments were performed by alternating single ozonation and catalytic ozonation with $\gamma-\mathrm{Al}_{2} \mathrm{O}_{3}$ in order to observe the by-products adsorption capacity of $\gamma-\mathrm{Al}_{2} \mathrm{O}_{3}$. The authors explain that carboxylates could be adsorbed onto $\gamma-\mathrm{Al}_{2} \mathrm{O}_{3}$ when the solution $\mathrm{pH}$ is lower than the $\mathrm{pH}_{\mathrm{PZC}}$ of the material [2]. On the other hand, 2,4-dimethylphenol (2,4-DMP) removal was performed by single ozonation in order to generate oxidized by-products and, , then $\gamma-\mathrm{Al}_{2} \mathrm{O}_{3}$ was added to examine its adsorption ability [17]. These experiments clearly evidenced no adsorption of the oxidized by-products generated after $35 \mathrm{~min}$ of single ozonation, but an adsorption of the by-products generated after $3 \mathrm{~h}$ of single ozonation. Consequently, it appears that reaction mechanisms in aluminum oxides/ozone processes are by-products dependent and are still unclear, especially concerning $\gamma-\mathrm{Al}_{2} \mathrm{O}_{3}$ material. The adsorption of oxidized by-products and the role of Lewis acid sites and basic sites of $\gamma-\mathrm{Al}_{2} \mathrm{O}_{3}$ are subject to large controversy.

In the present study, a commercial $\gamma-\mathrm{Al}_{2} \mathrm{O}_{3}$ with millimetric particles, suitable for industrial ozonation processes, was investigated for 2,4-DMP degradation in the presence of ozone, without adding any chemical, so without $\mathrm{pH}$ adjustment. Substituted phenols, such as 2,4-DMP are highly toxic compounds and are typical pollutants found in petrochemical wastewater $[25,26]$. The kinetics of pollutant degradation was followed, as well as the formation of the oxidized by-products by chromatography, by total organic carbon (TOC) and chemical oxygen demand (COD) measurements. Adsorption isotherms of 2,4-DMP and of the final oxidized by-products (carboxylic acids) on $\gamma-\mathrm{Al}_{2} \mathrm{O}_{3}$ were performed to clarify the adsorption capacity of $\gamma-\mathrm{Al}_{2} \mathrm{O}_{3}$. FTIR studies were performed to examine the acid and basic sites of the material before and after ozonation. The reusability of $\gamma-\mathrm{Al}_{2} \mathrm{O}_{3}$ was investigated by performing several ozonation runs of the pollutant. $\gamma-\mathrm{Al}_{2} \mathrm{O}_{3}$ was also used in the ozonation of a complex synthetic petrochemical effluent (phenol, acetic acid, naphtenic acid, pyrene, naphtalene) to confirm the observations obtained with 2,4-DMP. Toxicity tests were performed to evaluate the efficiency of $\gamma-\mathrm{Al}_{2} \mathrm{O}_{3}$ in ozonation.

\section{Experimental procedure}

\subsection{Materials}

Acetonitrile (ACN) and water $\left(\mathrm{H}_{2} \mathrm{O}\right)$ for high performance liquid chromatography (HPLC) analyzes are HPLC grade (Sigma Aldrich). $\gamma-\mathrm{Al}_{2} \mathrm{O}_{3}$ was purchased from Alpha Degussa. All other chemicals are high grade commercially available from Sigma Aldrich: 2,4dimethylphenol (2,4-DMP) (98\%), acetic acid, formic acid, oxalic acid, phenol, pyrene, naphtalene and tert-butanol ( $t$-BuOH). Naphtenic acid was purchased from Fluka. 2,4-DMP and carboxylic acids solutions were prepared using Millipore Milli-Q water.

\subsection{Inorganic materials characterization}

X-ray diffraction (XRD) pattern of the material was performed using a Bruker D8 Advance diffractometer with a Bragg-Brentano 
geometry and equipped with a Bruker Lynx Eye detector. XRD pattern was recorded in the range $4^{\circ}-85^{\circ}(2 \theta)$ with a $0.0197^{\circ}$ angular step size and a $0.2 \mathrm{~s}$ counting time per step. Textural properties of the material were determined by $\mathrm{N}_{2}$ adsorption/desorption at $-196^{\circ} \mathrm{C}$ on a Micromeritics Tristar 3000 apparatus. The sample was previously outgassed in vacuum at $250^{\circ} \mathrm{C}$ for $12 \mathrm{~h}$. The surface area was determined according to the BET method. Total pore volume was calculated at the end of the adsorption step. Mesopore diameter was evaluated using the Broekhoff and De Boer method applied to the desorption branch of the isotherm as it has been shown to be one of the more accurate method for mesopore size evaluation [27].

The ${ }^{13} \mathrm{C}$ MAS NMR spectrum of $\gamma-\mathrm{Al}_{2} \mathrm{O}_{3}$ after $5 \mathrm{~h}$ ozonation was performed on filtered and dried material and was obtained on a Varian VNMRS $300 \mathrm{MHz}$ spectrometer with a magnetic field of $7.05 \mathrm{~T}$. The operating frequency for ${ }^{13} \mathrm{C}$ was $75.43 \mathrm{MHz}$. The sample was packed in a $7.5 \mathrm{~mm} \mathrm{ZrO}_{2}$ rotor. The chemical shifts are presented in parts per million.

FTIR analyses of $\gamma-\mathrm{Al}_{2} \mathrm{O}_{3}$ were performed on dried materials before and after ozonation. Samples were pressed ( $\sim 10^{6}$ Torr $)$ into self-supported disks $\left(2 \mathrm{~cm}^{2}\right.$ area, $\left.7-10 \mathrm{mg} \mathrm{cm}^{-2}\right)$ and placed in a quartz cell equipped with $\mathrm{KBr}$ windows. A movable quartz sample holder permits one to adjust the pellet in the infrared beam for spectra recording and to displace it into a furnace at the top of the cell for thermal treatment. The cell was connected to a vacuum line for evacuation ( $P_{\text {residual }} \approx 10^{-6}$ Torr) and for the introduction of gases into the infrared cell. The gas pressure inside the cell was measured by a pressure gauge $\left(10^{-2}-10^{3}\right.$ Torr range). A Bruker Vertex $80 \mathrm{~V}$ spectrometer equipped with a mercury cadmium telluride (MCT) cryodetector and an extended $\mathrm{KBr}$ beam splitter was used for the acquisition of spectra recorded at room temperature, in the $600-5500 \mathrm{~cm}^{-1}$ range. The resolution of the spectra was $4 \mathrm{~cm}^{-1}$, and 128 scans were accumulated for each spectrum. Strength of acid sites of the materials was obtained by pyridine adsorption followed by FTIR spectroscopy for different temperatures of desorption. Basic sites of the materials were analyzed by $\mathrm{CO}_{2}$ adsorption/desorption.

\subsection{Adsorption and ozonation experiments}

Prior to ozonation experiments, 2,4-DMP adsorption capacity of $\gamma-\mathrm{Al}_{2} \mathrm{O}_{3}$ was assessed to quantify its possible contribution to the degradation of the pollutant. Adsorption of the pollutant was performed at $25^{\circ} \mathrm{C}$ in abiotic conditions: $0.2 \mathrm{~g}$ of $\gamma-\mathrm{Al}_{2} \mathrm{O}_{3}$ were stirred in a glass bottle containing $100 \mathrm{~mL}$ of pollutant solution until the equilibrium was reached, which was corresponding to $4 \mathrm{~h}$. Equilibrium isotherms of adsorption were plotted for 2,4-DMP concentrations ranging from 1 to $400 \mathrm{mg} \mathrm{L}^{-1}$. Equilibrium isotherms of carboxylic acids adsorption (acetic acid, formic acid, oxalic acid) were performed following the same procedure than for 2,4-DMP adsorption.

The ozone decomposition of the pollutant was assessed in a glass stirred batch reactor of $2 \mathrm{~L}$ as previously described [18]. Experiments were conducted at $25^{\circ} \mathrm{C}$, feeding the reactor with a $40 \mathrm{Lh}^{-1}$ $\mathrm{O}_{3}$ gas flow rate with a $2 \mathrm{~g} \mathrm{Nm}^{-3} \mathrm{O}_{3}$ concentration (obtained from air). In a typical run, $3 \mathrm{~g}$ of $\gamma-\mathrm{Al}_{2} \mathrm{O}_{3}$ were added in the reactor with $1.5 \mathrm{~L}$ of $2,4-\mathrm{DMP}$ solution at $50 \mathrm{mg} \mathrm{L}^{-1}$. The solution was stirred at $400 \mathrm{rpm}$ at $25^{\circ} \mathrm{C}$ and $\mathrm{O}_{3}$ was injected to the reactor immediately after introducing $\gamma-\mathrm{Al}_{2} \mathrm{O}_{3}$. In order to avoid limitation by $\mathrm{O}_{3}$ gas to liquid transfer, the stirring velocity of the reactor was optimized by progressively increasing the velocity from 200 to $400 \mathrm{rpm}$ and optimal stirrer velocity was found at $400 \mathrm{rpm}$ [18]. The pollutant removal and its oxidized by-products were monitored taking samples within time through PTFE syringe filters $(0.45 \mu \mathrm{m})$.

The reuse and regeneration of $\gamma-\mathrm{Al}_{2} \mathrm{O}_{3}$ were also investigated by performing several ozonation runs of the 2,4-DMP degradation.
These experiments were performed using another lab scale reactor described elsewhere [17], similar to the first one but with a volume of solution of $2 \mathrm{~L}$, an amount of $\gamma-\mathrm{Al}_{2} \mathrm{O}_{3}$ of $5 \mathrm{~g} \mathrm{~L}^{-1}$, a $\mathrm{O}_{3}$ gas flow rate is $30 \mathrm{~L} \mathrm{~h}^{-1}$ and $\mathrm{O}_{3}$ gas concentration is $5 \mathrm{~g} \mathrm{Nm}^{-3}$ (obtained from $\mathrm{O}_{2}$ ).

A synthetic petrochemical effluent was also ozonized with $\gamma$ $\mathrm{Al}_{2} \mathrm{O}_{3}$ without and with $\mathrm{NaCl}\left(50 \mathrm{~g} \mathrm{~L}^{-1}\right)$. These experiments were performed in a third pilot plant scale reactor described elsewhere [28] with a volume of solution of $1.5 \mathrm{~L}$, an amount of $\gamma-\mathrm{Al}_{2} \mathrm{O}_{3}$ of $2 \mathrm{~g} \mathrm{~L}^{-1}, \mathrm{a} \mathrm{O}_{3}$ gas flow rate of $24 \mathrm{Lh}^{-1}$ and a gas concentration of $5 \mathrm{~g} \mathrm{O}_{3} \mathrm{Nm}^{-3}$. The complex synthetic effluent was a mixture of several aromatic hydrocarbons and associated acids: phenol, acetic acid, naphtenic acid, pyrene, naphtalene with initial concentration of $200,200,25,0.05,0.95 \mathrm{mg} \mathrm{L}^{-1}$, respectively, corresponding to $\mathrm{TOC}=230 \mathrm{mg} \mathrm{L}^{-1}$ and $\mathrm{COD}=750 \mathrm{mg} \mathrm{L}^{-1}$. Toxicity tests were performed on the experiments performed in presence of $\mathrm{NaCl}\left(50 \mathrm{~g} \mathrm{~L}^{-1}\right)$. Non-standardized toxicity tests (Toxkits), named ARTOXKIT and ROTOXKIT, were performed using two different seawater organisms Artemia franciscana and Brachionus calyciflorus, respectively. Toxicity tests were performed after $\mathrm{pH}$ adjustment at $\mathrm{pH} 7$ of the effluent treated by 150 and $300 \mathrm{~min}$ of ozonation with $\gamma-\mathrm{Al}_{2} \mathrm{O}_{3}$. The efficiency of the process was assessed by the effluent concentration able to provoke $50 \%$ mortality of the species after $24 \mathrm{~h}$ of exposure ( $\mathrm{LC}_{50} 24 \mathrm{~h}$ ). Results were expressed in toxic unit: Equitox $/ \mathrm{m}^{3}=100 / \mathrm{LC}_{50} 24 \mathrm{~h}$.

\subsection{Analysis of soluble pollutant and by-products}

The 2,4-DMP concentration in the aqueous solutions was monitored by HPLC (Waters 600E controller and pump, 717 plus Autosampler) equipped with an UV detector (2996 PDA, fixed wavelength $\lambda=279 \mathrm{~nm}$ ). HPLC analyzes was performed on a C18 grafted silica column (Interchim, Uptisphere ${ }^{\circledR}$ C18-ODB, $150 \mathrm{~mm} \times 4.6 \mathrm{~mm} \times 5 \mu \mathrm{m}) .20 \mu \mathrm{l}$ sample were injected and a mobile phase composed of $45 / 55\left(\mathrm{ACN} / \mathrm{H}_{2} \mathrm{O}\right)$ at $0.8 \mathrm{ml} \mathrm{min}^{-1}$ was used. Solutions were filtered before analysis with a PTFE syringe filter $(0.45 \mu \mathrm{m})$. Under these analytical conditions, the retention time of 2,4-DMP was about $5 \mathrm{~min}$.

The total organic carbon (TOC) values of the solutions were determined with a Shimadzu TOC-V meter. The gas flow-rate (air) was set to $130 \mathrm{~mL} \mathrm{~min}^{-1}$ and the gas pressure was $190 \mathrm{kPa}$. The TOC measurement is based on the oxidation of the organic matter (except volatile organic compounds) by thermal oxidation. The solution is first acidified with $\mathrm{HCl}(2 \mathrm{~N})$ to transform carbonates into $\mathrm{CO}_{2}$. Air is then bubbled in the solution to remove $\mathrm{CO}_{2}$. Samples are then injected in an oven heated at $680^{\circ} \mathrm{C}$ containing a catalyst (Pt) to transform the organics into $\mathrm{CO}_{2}$, which is therefore analyzed by an IR detector.

The chemical oxygen demand (COD) is the quantity of oxygen necessary to chemically oxidize all molecules in water. This analysis is performed using oxidation with $\mathrm{K}_{2} \mathrm{Cr}_{2} \mathrm{O}_{7}$ in closed containers in acidic medium in presence of $\mathrm{Ag}_{2} \mathrm{SO}_{4}$ catalyst. $\mathrm{HgSO}_{4}$ is also added to precipitate chloride anions. After addition of $2 \mathrm{~mL}$ of polluted water solution in tubes containing the oxidative reactants at different concentrations to analyze COD between 0 and $150 \mathrm{mg}_{\mathrm{O}_{2}} \mathrm{~L}^{-1}$ (purchased to Hash), the mixtures were heated at $150^{\circ} \mathrm{C}$ for $2 \mathrm{~h}$. The amount of produced $\mathrm{Cr}^{3+}$ was measured by spectrophotometry (Hash instrument) at $600 \mathrm{~nm}$, which allowed to calculate COD.

The carboxylic acids concentrations were determined by ionic chromatography (IC) using a Dionex ICS 1000 system equipped with an ASRS $4 \mathrm{~mm}$ ionization system and a Dionex AS19 column. $25 \mu \mathrm{l}$ samples were injected. Eluent was a $\mathrm{KOH}$ solution at $1 \mathrm{~mL} \mathrm{~min}^{-1}$ and with the following gradient conditions: $10 \mathrm{mM}$ from 0 to $10 \mathrm{~min}$, then $45 \mathrm{mM}$ from 10 to $40 \mathrm{~min}$ and finally $10 \mathrm{mM}$ from 40 to $50 \mathrm{~min}$.

LC-MS analyses were achieved with a UPLC Acquity H-Class (Waters) and a Synapt G2-S (Waters) detector equipped with a 


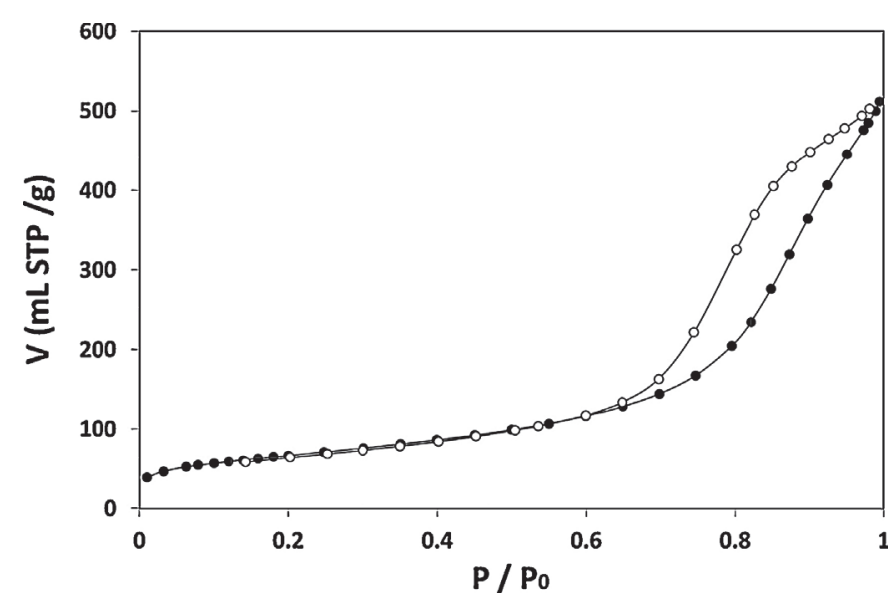

Fig. 1. $\mathrm{N}_{2}$ adsorption $(\bullet)$ and desorption $(\bigcirc)$ isotherms of $\gamma-\mathrm{Al}_{2} \mathrm{O}_{3}$ at $-196^{\circ} \mathrm{C}$.

dual electro-spray (EScl). $10 \mu \mathrm{L}$ samples were injected, a column Acquity BEH I was used $(\mathrm{C} 18,50 \mathrm{~mm} \times 2.1 \mathrm{~mm} \times 1.7 \mu \mathrm{m})$ and the mobile phase was constituted of $\mathrm{ACN}$ and $\mathrm{H}_{2} \mathrm{O}$ at $0.8 \mathrm{ml} \mathrm{min}^{-1}$.

\section{Results and discussion}

\subsection{Characterization of $\gamma-\mathrm{Al}_{2} \mathrm{O}_{3}$}

$\gamma-\mathrm{Al}_{2} \mathrm{O}_{3}$ was purchased as $3-5 \mathrm{~mm}$ cylindrical pellets (Fig. S1), which is a suitable size for industrial ozonation processes. XRD pattern indicated principally three broad peaks around 35,45 and $66^{\circ}$ in $2 \theta$ (Fig. S2), which showed the gamma crystalline phase of this alumina oxide [29]. $\mathrm{N}_{2}$ adsorption/desorption isotherm of $\gamma-\mathrm{Al}_{2} \mathrm{O}_{3}$ is of type IV according to IUPAC classification characteristic of a mesoporous material (Fig. 1). A hysteresis loop (H1) was observed at high relative pressures revealing cylindrical pores of mean pore diameter of $15 \mathrm{~nm}$. The material featured a BET specific surface area of $236 \mathrm{~m}^{2} \mathrm{~g}^{-1}$ and a mesopore volume of $0.60 \mathrm{~cm}^{3} \mathrm{~g}^{-1}$.

\subsection{Adsorption of 2,4-DMP on $\gamma-\mathrm{Al}_{2} \mathrm{O}_{3}$}

Prior to $\mathrm{O}_{3}$ experiments, adsorption of the pollutant on $\gamma-\mathrm{Al}_{2} \mathrm{O}_{3}$ was verified to assess the adsorption contribution in the 2,4-DMP removal. First, adsorption kinetic was monitored at $25^{\circ} \mathrm{C}$ by stirring a 2,4-DMP solution ( $\left.50 \mathrm{mg} \mathrm{L}^{-1}\right)$ with $\gamma-\mathrm{Al}_{2} \mathrm{O}_{3}\left(2 \mathrm{~g} \mathrm{~L}^{-1}\right)$ in order to estimate the time necessary to reach equilibrium. The expected maximum adsorption would be $25 \mathrm{mg}$ 2,4-DMP per gram $\gamma-\mathrm{Al}_{2} \mathrm{O}_{3}$. Equilibrium was reached after $4 \mathrm{~h}$ and only $0.2 \mathrm{mg} 2,4-\mathrm{DMP}$ per gram $\gamma-\mathrm{Al}_{2} \mathrm{O}_{3}$ was obtained. The 2,4-DMP adsorption isotherm was then built for an equilibrium time of $4 \mathrm{~h}$ and by varying the 2,4-DMP concentration from 1 to $400 \mathrm{mg} \mathrm{L}^{-1}$. For the highest 2,4-DMP concentration $\left(400 \mathrm{mg} \mathrm{L}^{-1}\right)$ only $3.2 \mathrm{mg}$ 2,4-DMP were adsorbed per gram of $\gamma-\mathrm{Al}_{2} \mathrm{O}_{3}$ (Fig. S3). Therefore, in this study (using a 2,4-DMP solution of $50 \mathrm{mg} \mathrm{L}^{-1}$ ) the contribution of the pollutant adsorption in the ozonation process can be neglected.

\subsection{Ozonation of 2,4-DMP in aqueous solution with and without $\gamma-\mathrm{Al}_{2} \mathrm{O}_{3}$}

Ozonation experiments were conducted with 2,4-DMP solutions $\left(50 \mathrm{mg} \mathrm{L}^{-1}\right)$ at $25^{\circ} \mathrm{C}$ with an initial $\mathrm{pH}$ of deionized water around 4.5. No chemicals were added in the solution in accordance of industrial process requirement (no buffer or base added). The $\mathrm{pH}$ was continuously measured but not controlled. The $\mathrm{pH}$ value of the 2,4-DMP solutions with and without $\gamma-\mathrm{Al}_{2} \mathrm{O}_{3}$ was monitored during the ozonation experiments (Fig. S4). The pollutant removal over time was monitored as well as the total organic carbon (TOC) (a)

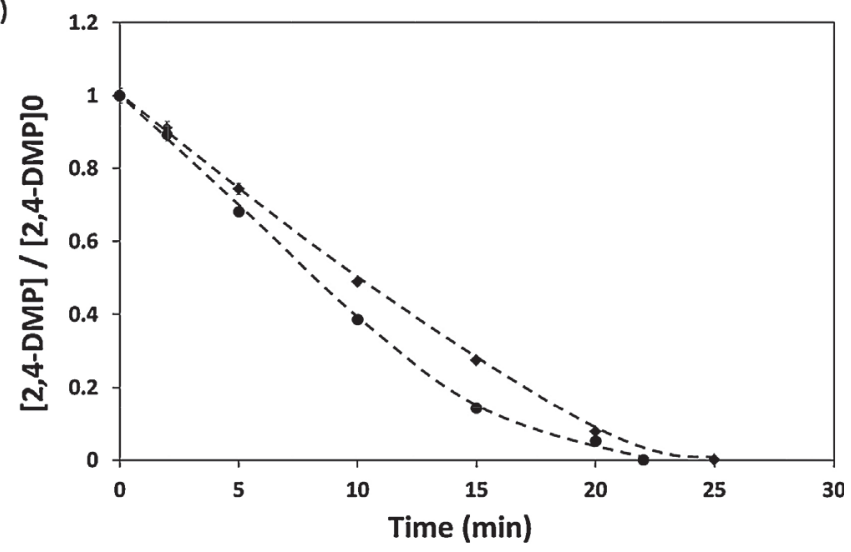

(b)

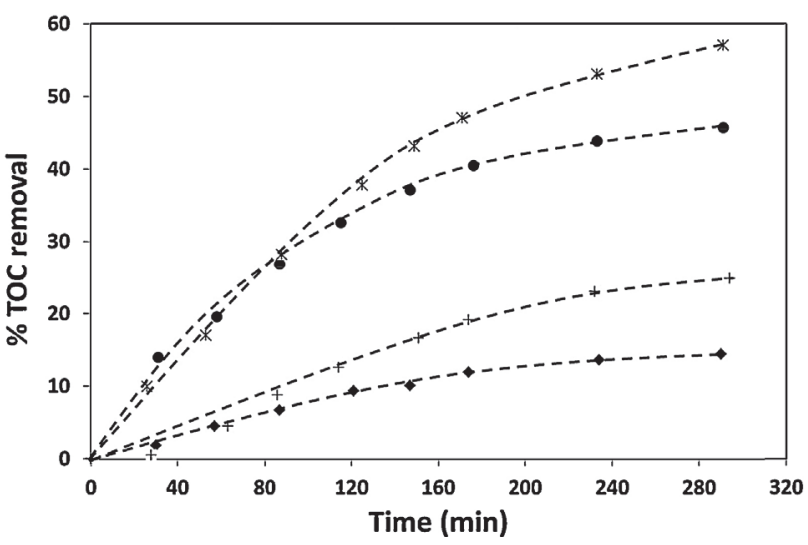

Fig. 2. 2,4-DMP removal (a) and TOC removal (b) during single ozonation ( $\downarrow$ ) and during ozone $/ \gamma-\mathrm{Al}_{2} \mathrm{O}_{3}$ coupled treatment with different amount of $\gamma-\mathrm{Al}_{2} \mathrm{O}_{3}: 1 \mathrm{~g} \mathrm{~L}^{-1}$ $(+) ; 2 \mathrm{gL}^{-1}(\bullet) ; 5 \mathrm{~g} \mathrm{~L}^{-1}\left({ }^{*}\right)$. Temperature: $25^{\circ} \mathrm{C} . \mathrm{O}_{3}$ flow rate: $40 \mathrm{Lh}^{-1} \cdot\left[\mathrm{O}_{3}\right]_{\text {Inlet }}: 2 \mathrm{~g}$ $\mathrm{Nm}^{-3}$. [2,4-DMP $]_{0}: 50 \mathrm{mg} \mathrm{L}^{-1}$. Volume of solution: $1.5 \mathrm{~L}$.

(Fig. 2) and the chemical oxygen demand (COD) (Fig. 3; Table 1) with and without $\gamma-\mathrm{Al}_{2} \mathrm{O}_{3}$. Some 2,4-DMP oxidized by-products were identified and followed within time (Table 2).

\subsubsection{Removal of 2,4-DMP from the water solution}

By single ozonation (without materials) 2,4-DMP was totally removed from the solution after 25 min even with low ozone concentration $\left(2 \mathrm{~g} \mathrm{Nm}^{-3}\right)$ (Fig. 2a). Similar fast 2,4-DMP removal by single ozonation was also previously noticed with similar initial concentration indicating a high reactivity of this pollutant with ozone $[17,18,30]$. Adding $\gamma-\mathrm{Al}_{2} \mathrm{O}_{3}\left(2 \mathrm{~g} \mathrm{~L}^{-1}\right)$ in the ozonation process led to a slight increase of 2,4-DMP removal rate with a complete removal after $22 \mathrm{~min}$ (Fig. 2a), as observed also previously using zeolites in similar conditions $[17,18]$. The initial degradation of 2,4DMP seems independent of the presence of any inorganic catalysts and encountered presumably to fast direct reaction of ozone with 2,4-DMP. Ozone reacts preferentially with organic molecules featuring double bounds (Scheme 1) and activated aromatics. 2,4-DMP is an aromatic molecule substituted by three electron donor groups (one hydroxyl strongly $\mathrm{e}^{-}$donor and two methyl) and is therefore very favorable to ozonation degradation. Two simplified pathways can be imagined for direct ozonation of 2,4-DMP due to the

Table 1

Rate constants for COD removal during 2,4-DMP ozonation for single ozonation and ozonation with $\gamma-\mathrm{Al}_{2} \mathrm{O}_{3}$.

\begin{tabular}{lcl}
\hline & $k_{\text {COD fast }} \times 10^{5}\left(\mathrm{~s}^{-1}\right)$ & $k_{\text {COD slow }} \times 10^{5}\left(\mathrm{~s}^{-1}\right)$ \\
\hline Single ozonation & $7.8 \pm 0.1$ & $1.1 \pm 0.1$ \\
$\mathrm{O}_{3} / \gamma-\mathrm{Al}_{2} \mathrm{O}_{3}$ & $11.9 \pm 0.1$ & $5.8 \pm 0.1$ \\
\hline
\end{tabular}


(a)

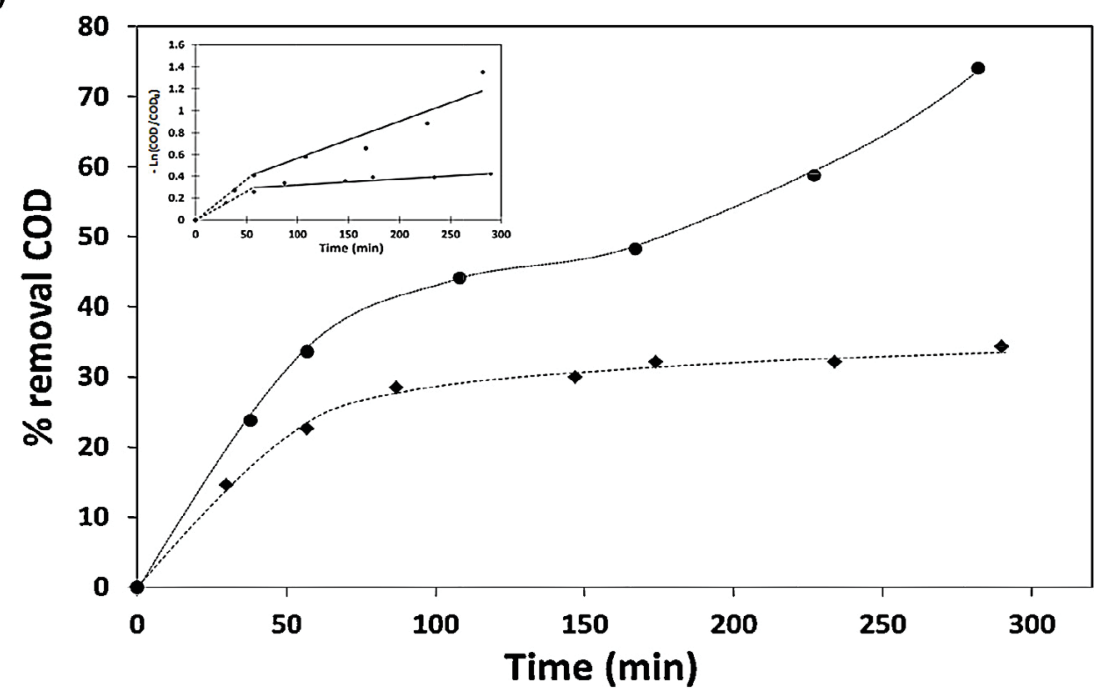

(b)

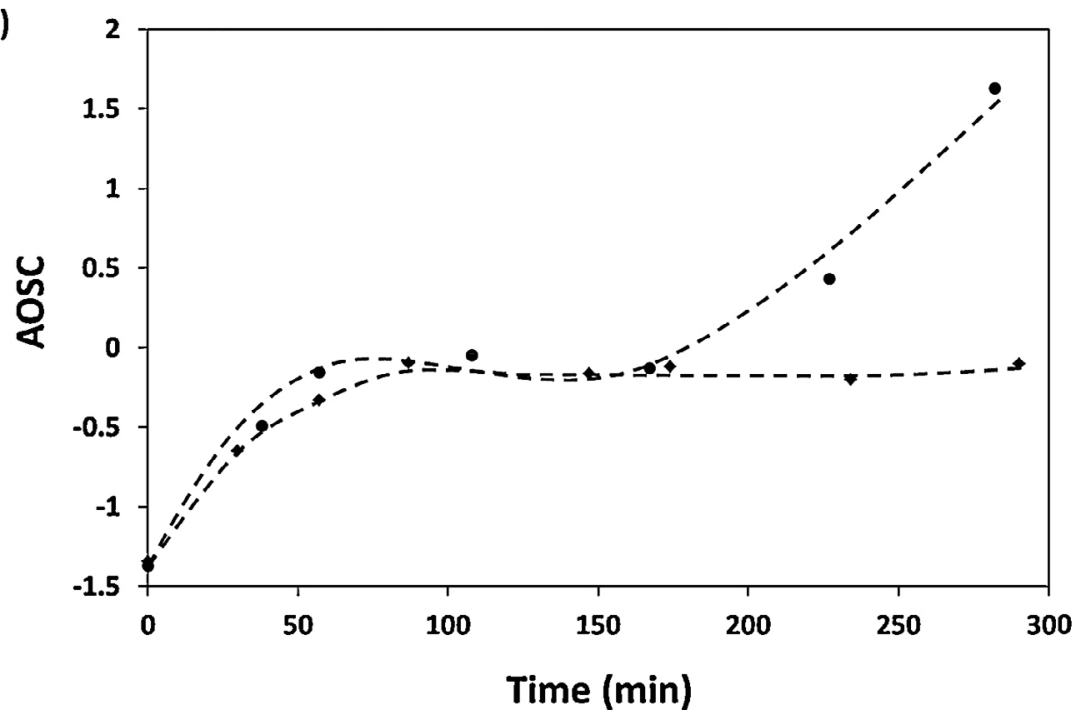

Fig. 3. COD removal (Inset: logarithm representation for rate constant calculation) (a) and $\mathrm{AOSC}$ factor evolution (b) during single ozonation ( $\downarrow$ ) and during ozone $/ \gamma-\mathrm{Al}_{2} \mathrm{O}_{3}$ coupled treatment $(\bullet)$. Temperature: $25^{\circ} \mathrm{C} ; \mathrm{O}_{3}$ flow rate: $40 \mathrm{~L} \mathrm{~h}^{-1} ;\left[\mathrm{O}_{3}\right]_{\text {Inlet }}: 2 \mathrm{~g} \mathrm{Nm}^{-3} ;[2,4-\mathrm{DMP}]_{0}: 50 \mathrm{mg} \mathrm{L}^{-1}$; volume of solution: $1.5 \mathrm{~L} ; \gamma$ - $\mathrm{Al}_{2} \mathrm{O}_{3}: 2 \mathrm{~g} \mathrm{~L}^{-1}$.

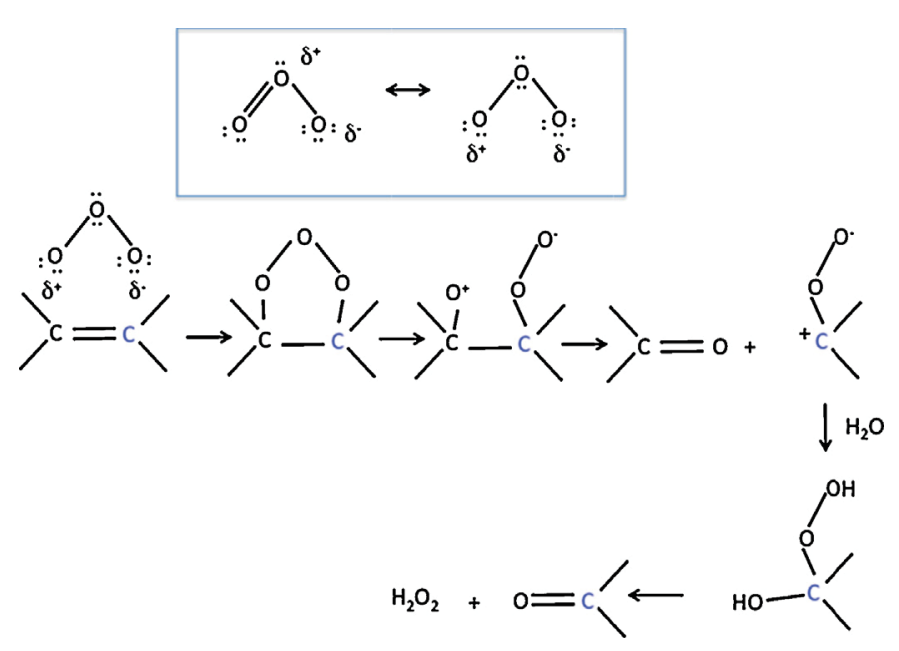

Scheme 1. Schematic representation of direct $\mathrm{O}_{3}$ reaction with unsaturated bond. polarizability of the double bond bearing the OH group (Scheme 2). Different intermediary by-products are however expected as for nitrobenzene ozonation [31]. Expected final products are carboxylic acids. They are very stable against ozonation as acetic acid but not formic acid, which reacts with ozone to give $\mathrm{CO}_{2}$.

\subsubsection{Removal of total organic carbon from the water solution}

The removal of specific pollutant (as 2,4-DMP in our case) is one of the objectives of the water treatment. However, the efficiency of a water treatment process should also assess the amount of total organic carbons (TOC) remaining in the solution resulting from the degradation of the initial product. Indeed oxidized by-products of pollutants may have also a toxic character and sometimes are even more toxic than the initial pollutant, as it will be shown in the last part of this study. So, it is of prime importance to estimate the oxidation efficiency of a water treatment process through TOC measurement [32,33]. If no adsorption of pollutants or by-products is noticed, TOC removal corresponds to the mineralization level of the pollutant. Concerning single ozonation, only $14 \%$ TOC removal was reached after $5 \mathrm{~h}$ ozonation. Adding 
Table 2

Identification by LC-MS of some 2,4-DMP oxidized by-products after single ozonation and ozonation with $\gamma-\mathrm{Al}_{2} \mathrm{O}_{3}$.

\begin{tabular}{|c|c|c|c|c|c|}
\hline \multirow{2}{*}{$\begin{array}{l}\text { 2,4-DMP oxidized } \\
\text { by-products }\end{array}$} & \multirow[t]{2}{*}{$m / z$} & \multicolumn{2}{|l|}{$\mathrm{O}_{3}$} & \multicolumn{2}{|c|}{$\mathrm{O}_{3} / \gamma-\mathrm{Al}_{2} \mathrm{O}_{3}$} \\
\hline & & $t_{\mathrm{r}}(\mathrm{min})$ & $t_{\mathrm{d}}(\min )$ & $t_{\mathrm{r}}(\min )$ & $t_{\mathrm{d}}(\min )$ \\
\hline
\end{tabular}<smiles>Cc1cc(C)c(O)c(C)c1</smiles><smiles>CCCCCOc1ccccc1</smiles>
$139 \quad 1.30$ 61<smiles>[Os]c1ccccc1</smiles><smiles>Cc1ccccc1C=O</smiles>

$\mathrm{C}_{8} \mathrm{H}_{8} \mathrm{O}$<smiles>Cc1cc(C)c(OC(=O)C(=O)O)c(O)c1</smiles>

$\mathrm{C}_{10} \mathrm{H}_{10} \mathrm{O}_{5}$ 21

$t_{\mathrm{r}}$ : retention time; $t_{\mathrm{d}}$ : complete removal time.

$\gamma-\mathrm{Al}_{2} \mathrm{O}_{3}\left(2 \mathrm{~g} \mathrm{~L}^{-1}\right)$ to the ozonation process allowed a remarkable increase of the TOC removal corresponding to $46 \%$ of organic carbons removal (Fig. 2b). TOC removal increased linearly during about $60 \mathrm{~min}$ and then became slower (especially after ca. $170 \mathrm{~min}$ ), which probably indicated that some oxidized by-products are very stable towards ozonation. Moreover, this slowdown in the mineralization rate can be explained by the low ozone dosage chosen in this study $\left(2 \mathrm{~g} \mathrm{Nm}^{-3}\right)$ in comparison with usual industrial conditions ( 25 to $100 \mathrm{~g} \mathrm{Nm}^{-3}$ ). Increasing the amount of $\gamma-\mathrm{Al}_{2} \mathrm{O}_{3}$ from 1 to $5 \mathrm{~g} \mathrm{~L}^{-1}$ in the ozonation process yielded to an increase of TOC removal from 26 to 57\%, respectively. However, TOC removal

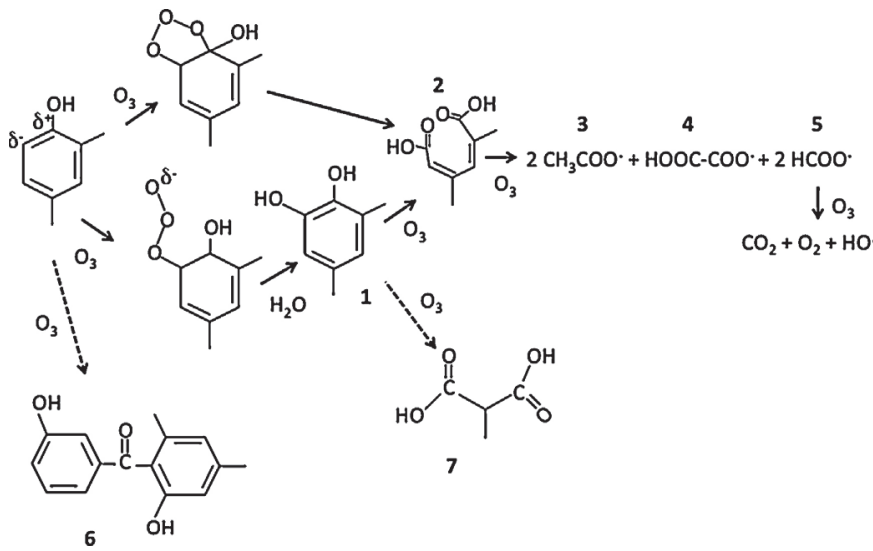

Scheme 2. Schematic representation of expected direct $\mathrm{O}_{3}$ reaction with 2,4-DMP (plain arrows). Possible dimerization route (6) and methylmalonic acid (7) formation is presented in dashed line. efficiencies for 2 and $5 \mathrm{~g} \mathrm{~L}^{-1} \gamma-\mathrm{Al}_{2} \mathrm{O}_{3}$ were overlapping during 90 min of reaction. We may explain this fact considering two parallel reactions: catalytic ozonation and adsorption on $\gamma-\mathrm{Al}_{2} \mathrm{O}_{3}$ of highly oxidized by-products formed after 90 min ozonation. Similar catalytic ozonation efficiency between 2 and $5 \mathrm{~g} \mathrm{~L}^{-1} \gamma-\mathrm{Al}_{2} \mathrm{O}_{3}$ is suspected, whereas adsorption ability of highly oxidized by-products is enhanced with higher amount of $\gamma-\mathrm{Al}_{2} \mathrm{O}_{3}$ adsorbent.

\subsubsection{Chemical oxygen demand (COD) removal}

The chemical oxygen demand (COD) is another way to indirectly measure the amount of organic compounds remaining in water. TOC measures the organic matter that can be oxidized by thermal treatment (expressed in $\mathrm{mg}$ of $\mathrm{C}$ per L), whereas COD measures the organic matter that can be oxidized chemically. COD is expressed in mg of $\mathrm{O}_{2}$ per L, which indicates the mass of oxygen consumed per liter of solution to oxidize organics [11]. Single 2,4-DMP ozonation led to 35\% COD removal corresponding to a decrease from 130 to $83 \mathrm{mg}_{2} \mathrm{~L}^{-1}$ after $5 \mathrm{~h}$ treatment. Similarly to the TOC evolution, the COD decreased more rapidly in the presence of $\gamma-\mathrm{Al}_{2} \mathrm{O}_{3}$. Indeed, adding $\gamma-\mathrm{Al}_{2} \mathrm{O}_{3}\left(2 \mathrm{~g} \mathrm{~L}^{-1}\right)$ in the process allowed a significant reduction of the COD from 143 to $37 \mathrm{mg}_{2} \mathrm{~L}^{-1}$, corresponding to $75 \%$ COD removal. The kinetics of COD removal was modeled using a two-pathways first-order kinetic model [2]. This model distinguishes organic compounds oxidizing fast during the ozonation experiments from those oxidizing slowly. The experimental data for fast and slow oxidations were fitted with the first order kinetic model (Eq. (1)) and reported in Fig. 3a. In each pathway of the model the corresponding rate constants for COD removal were higher in the presence of $\gamma-\mathrm{Al}_{2} \mathrm{O}_{3}$ (Table 1 ). The change of regime was clearly observed after $60 \mathrm{~min}$ of ozonation (Fig. 3a).

$$
\begin{aligned}
& \frac{\mathrm{d}[\mathrm{COD}]_{\mathrm{x}}}{\mathrm{dt}}=\mathrm{k}[\mathrm{COD}]_{\mathrm{x}} \\
& \frac{\mathrm{d}[\mathrm{COD}]_{\mathrm{x}}}{[\mathrm{COD}]_{\mathrm{x}}}=\mathrm{kdt} \\
& -\ln \left(\frac{\mathrm{COD} D_{\mathrm{x}}}{\mathrm{COD}_{0}}\right)=\mathrm{kt}+\text { constant }
\end{aligned}
$$

with $x=$ fast or slow.

An interesting factor to consider is the average oxidation state of carbon (AOSC) [2,34,35], which informs indirectly about the average oxidation state of the organic compounds remaining in the solution by comparing thermal oxidation (TOC) with chemical oxidation (COD) according to Eq. (2).

$\mathrm{AOSC}=4-\left(4 \times 0.375 \frac{\mathrm{COD}}{\mathrm{TOC}}\right)$

with 0.375 being the ratio between the molecular mass of $\mathrm{C}$ and $\mathrm{O}_{2}$ to expressed COD and TOC in mmol.

Higher AOSC values will be obtained for higher oxygenated molecules. AOSC values are in the range $[-4$ to +4$]$ with -4 accounting for low oxidation state as methane and +4 for high oxidation state as $\mathrm{CO}_{2}$. The AOSC value of the starting 2,4-DMP solution is around -1.4 , as the average oxidation state of the molecule is low. For single ozonation, the average oxidation level of the organic compounds increased to -0.2 after $4 \mathrm{~h}$ indicating an increase of the average oxidation states of the organics in solution, which however remains low. Adding $\gamma-\mathrm{Al}_{2} \mathrm{O}_{3}$ during the ozonation process resulted in a three steps process: from 0 to $60 \mathrm{~min}$ (AOSC from -1.4 to -0.2 ), from 60 to $170 \mathrm{~min}(\mathrm{AOSC}=-0.2)$ and above $170 \mathrm{~min}$ with a remarkable increase of the AOSC from -0.2 to +1.6 between 3 and $5 \mathrm{~h}$ ozonation (Fig. 3b). This evidences that the by-products obtained after 170 min of ozonation with $\gamma-\mathrm{Al}_{2} \mathrm{O}_{3}$ are different to the one obtained by single ozonation and have a higher level of oxidation state. 


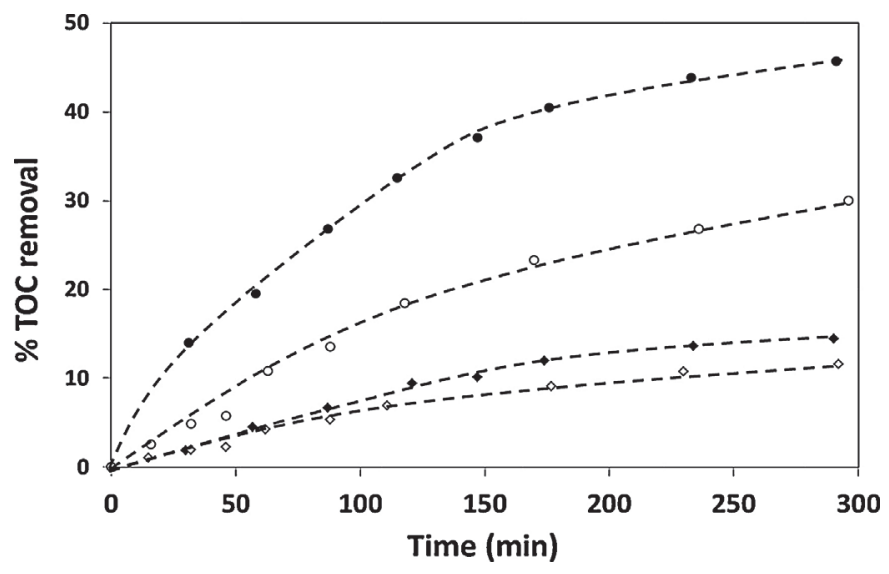

Fig. 4. TOC removal during single ozonation with $(\diamond)$ and without $(\diamond) t$-BuOH radical scavenger and during ozone $/ \gamma-\mathrm{Al}_{2} \mathrm{O}_{3}$ coupled treatment with $(\bigcirc)$ and without $(\bullet)$ $t$-BuOH. Temperature: $25^{\circ} \mathrm{C} ; \mathrm{O}_{3}$ flow rate: $40 \mathrm{Lh}^{-1} ;\left[\mathrm{O}_{3}\right]_{\text {Inlet }}: 2 \mathrm{~g} \mathrm{Nm}^{-3} ;[2,4-\mathrm{DMP}]_{0}$ : $50 \mathrm{mg} \mathrm{L}^{-1}$; volume of solution: $1.5 \mathrm{~L} ; \gamma-\mathrm{Al}_{2} \mathrm{O}_{3}: 2 \mathrm{~g} \mathrm{~L}^{-1}$; [t-BuOH]: $25 \mathrm{mg} \mathrm{L}^{-1}$.

\subsection{Ozonation of 2,4-DMP in presence of $\mathrm{HO}^{\bullet}$ radical scavenger $(\mathrm{t}-\mathrm{BuOH})$}

The $\mathrm{pH}$ value of the 2,4-DMP solutions with and without $\gamma$ $\mathrm{Al}_{2} \mathrm{O}_{3}$ was monitored during the ozonation experiments (Fig. S4). For single ozonation, a decrease in the $\mathrm{pH}$ value was observed from 4.0 to 2.8 . This is very likely due to the formation of carboxylic acids during ozonation as reported elsewhere [36-39]. A higher $\mathrm{pH}$ decrease was noticed for ozonation in presence of $\gamma-\mathrm{Al}_{2} \mathrm{O}_{3}$ from 4.5 to 2.5 after $5 \mathrm{~h}$. In both cases (with and without $\gamma-\mathrm{Al}_{2} \mathrm{O}_{3}$ ) the promotion of $\mathrm{HO}^{\bullet}$ radicals due to basic $\mathrm{pH}$ is not possible due to very low $\mathrm{OH}^{-}$concentration at the $\mathrm{pH}$ of this study. As mentioned previously, $\mathrm{O}_{3}$ can react by two routes in aqueous media: the direct $\mathrm{O}_{3}$ ozonation (Schemes 1 and 2) and the radical type reaction. This later route implies the generation of $\mathrm{HO}^{\bullet}$ radicals during ozone self-decomposition. The radical reaction is more efficient for removing refractory compounds $[3,8]$. In order to evidence $\mathrm{HO}^{\bullet}$ generation in the ozonation with $\gamma-\mathrm{Al}_{2} \mathrm{O}_{3}$ a stable radical scavenger as tert-butanol ( $t$-BuOH at $\left.25 \mathrm{mg} \mathrm{L}^{-1}\right)$ was introduced in the $2,4-$ DMP solution. This amount of $t-\mathrm{BuOH}$ was previously demonstrated to be enough in heterogeneous catalytic ozonation to annihilate radical type reaction [40]. Single ozonation in presence of $t-\mathrm{BuOH}$ revealed a slight decrease in the TOC removal efficiency from 14 to $11 \%$ (Fig. 4) showing that single ozonation was principally governed by direct reaction of ozone with the organics present in the solution. For ozonation in the presence of $\gamma-\mathrm{Al}_{2} \mathrm{O}_{3}$, adding $t-\mathrm{BuOH}$ induced a decrease of the TOC removal from 46 to $30 \%$. This highlighted that $\gamma-\mathrm{Al}_{2} \mathrm{O}_{3}$ promotes the formation of $\mathrm{HO} \bullet$ as no $t-\mathrm{BuOH}$ was adsorbed on the material (not shown). As reported in several studies [16,20,22,24], the aluminum oxides might enhance free radicals generation due to their surface hydroxyl groups, which can interact with $\mathrm{O}_{3}$. However, as TOC removal in presence of $t-\mathrm{BuOH}$ remained higher (30\%) with $\gamma-\mathrm{Al}_{2} \mathrm{O}_{3}$ in comparison to single ozonation (11\%), it can be reasonably assumed that adsorption of oxidized by-products occurred on $\gamma-\mathrm{Al}_{2} \mathrm{O}_{3}$ and contributed to decrease the TOC of the solution. If the direct ozone reaction is at the same level with $\gamma-\mathrm{Al}_{2} \mathrm{O}_{3}$ than for single ozonation therefore $11 \%$, the contribution of adsorption in TOC removal for $\gamma-\mathrm{Al}_{2} \mathrm{O}_{3}$ could be $19 \%$ and the contribution of radical reaction $16 \%$.

\subsection{Identification of by-products obtained during 2,4-DMP ozonation}

\subsubsection{By-products identified by LC-MS during single ozonation}

As oxidized phenolic compounds are known to have a possible toxic character, their identification can give information about the toxicity level of the solution $[32,33]$. The identification of the first by-products from 2,4-DMP oxidation during single ozonation was attempted by LC-MS analysis. The non-exhaustive list of the products observed is presented in Table 2. Considering the products identified, several types of reactions were involved in the oxidation process:(i) Hydroxylation of the aromatic ring: hydroxylation of the aromatic ring, producing $\mathrm{C}_{8} \mathrm{H}_{10} \mathrm{O}_{2}$ (product 1 in Scheme 2) is consistent with hydroxylation products usually observed during phenol ozonation $[40,41]$. This by-product was the most abundant (Fig. S5). It appeared since the beginning of the reaction, reached an optimum after 25 min ozonation and was totally degraded after $61 \mathrm{~min}$ of reaction (Table 2).(ii) Opening of the aromatic ring by direct addition of ozone (Criegee mechanism): the identification of $\mathrm{C}_{8} \mathrm{H}_{10} \mathrm{O}_{4}$ (product 2 in Scheme 2) confirms that the direct addition of ozone on 2,4-DMP led to opening the aromatic ring and produced dimethyl muconic acid. Indeed, muconic acid is considered as one of the major transient products during ozonation of phenol $[41,42]$. This transient product was at its maximum in $20 \mathrm{~min}$ and was totally degraded after 91 min (Fig. S5; Table 2).(iii) Dimerization of 2,4-DMP: during the first minutes of ozonation the solution became turbid indicating the apparition of less soluble products. The compound $\mathrm{C}_{10} \mathrm{H}_{10} \mathrm{O}_{5}$ (Table 2; Fig. S5) has a higher molar mass than 2,4-DMP, which could result from the reaction of oxalic acid with $\mathrm{C}_{8} \mathrm{H}_{10} \mathrm{O}_{2}$ (product $\mathbf{1}$ in Scheme 2) and/or a degradation of a dimer. Dimerization of phenoxy radicals in acidic water was previously observed leading to non-soluble species [30,43]. Such a dimerization of dimethylphenols was also observed in oxidizing conditions in presence of ozone or copper [41,44,45]. Another compound $\mathrm{C}_{8} \mathrm{H}_{8} \mathrm{O}$ observed by LC-MS is considered as a by-product of $\mathrm{C}_{10} \mathrm{H}_{10} \mathrm{O}_{5}$ after several successive demethylations of the ring and decarboxylation of the aliphatic chain bonded with the first carbon of the aromatic ring. These two by-products were at their maximum at $15 \mathrm{~min}$ and were completed degraded after $91 \mathrm{~min}$ of ozonation (Fig. S5; Table 2).

\subsubsection{By-products identified by LC-MS during ozonation in the} presence of $\gamma-\mathrm{Al}_{2} \mathrm{O}_{3}$

During the degradation of the pollutant in presence of $\gamma-\mathrm{Al}_{2} \mathrm{O}_{3}$, LC-MS analyzes revealed the same by-products than for the single ozonation and thus the same oxidation pathways. The maximum apparition and the complete removal of these by-products occurred at the same time than for single ozonation. All of these by-products have been degraded after $90 \mathrm{~min}$ (Table 2; Fig. S5). The main difference consists in the amount of these by-products, which is much abundant in presence of $\gamma-\mathrm{Al}_{2} \mathrm{O}_{3}$ (except for $\mathrm{C}_{10} \mathrm{H}_{10} \mathrm{O}_{5}$, which was formed in similar amount) (Fig. S5).

\subsubsection{Identification and quantification of carboxylic acids obtained during single ozonation}

Ionic chromotography analysis allowed to identify and quantify the carboxylic acids formed during 2,4-DMP ozonation. Three carboxylic acids were mainly formed in the following increasing amount (Fig. 5a): acetic acid $>$ formic acid $\gg$ oxalic acid (products $\mathbf{3}, \mathbf{5}, \mathbf{4}$ in Scheme 2). Acetic acid was the most abundant reaching a plateau after $100 \mathrm{~min}$, which corresponded to a final concentration of $62 \mathrm{mg} \mathrm{L}^{-1}$. The formation of acetic acid is a consequence of an opening of the aromatic ring that could occur from the beginning of the ozonation reaction and of the oxidation of the by-products (Scheme 2). It must be noticed that acetic acid is a highly refractory molecule that is very stable against ozonation and will not be oxidized in formic acid or oxalic acid. The release of formic acid can correspond to a demethylation of 2,4DMP from the beginning of the reaction and/or to the oxidation of other by-products after several breakages of the $\mathrm{C}-\mathrm{C}$ bonds. The highest formic acid concentration $\left(28 \mathrm{mg} \mathrm{L}^{-1}\right)$ was observed after 60 min of reaction and then decreased to reach a concentration 
(a)

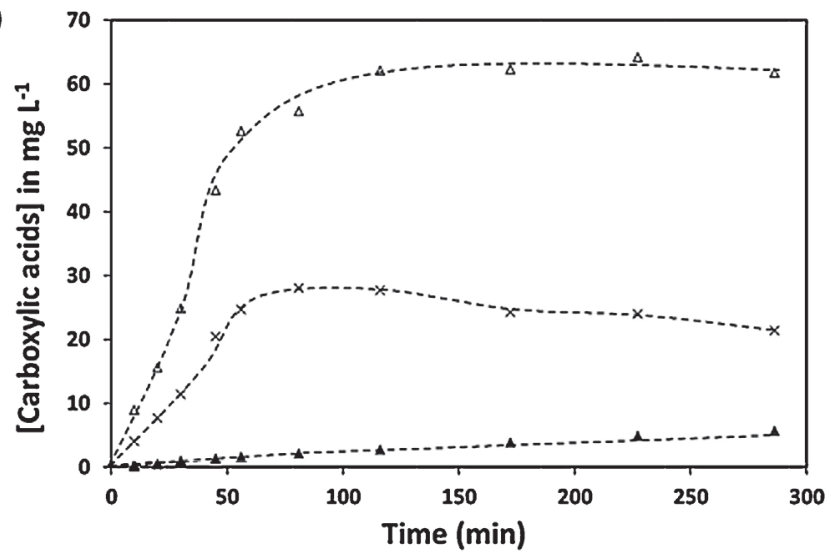

(b)

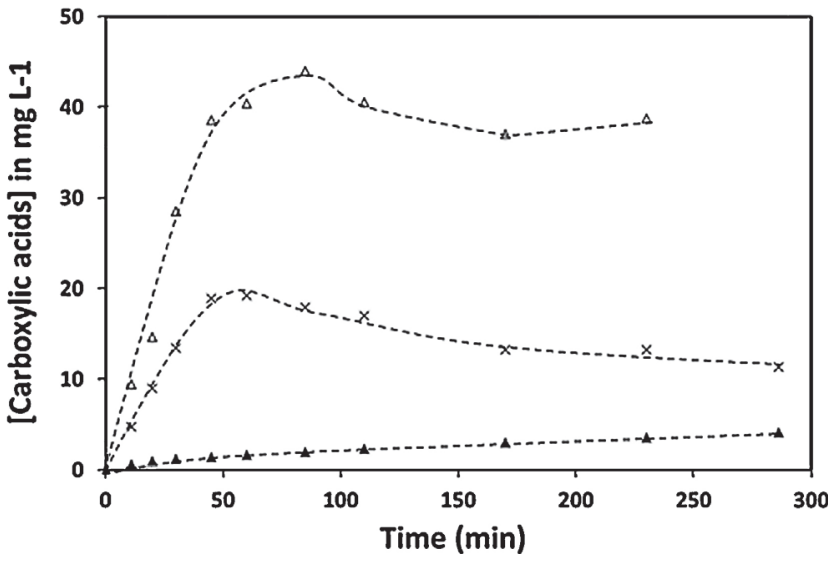

Fig. 5. Kinetic of acetic acid $(\triangle)$, formic acid $(x)$ and oxalic acid $(\Delta)$ formation during single ozonation (a) and during ozone $/ \gamma-\mathrm{Al}_{2} \mathrm{O}_{3}$ coupled treatment (b). Temperature: $25^{\circ} \mathrm{C} ; \mathrm{O}_{3}$ flow rate: $40 \mathrm{Lh}^{-1} ;\left[\mathrm{O}_{3}\right]_{\text {Inlet }}: 2 \mathrm{~g} \mathrm{Nm}^{-3} ;[2,4-\mathrm{DMP}]_{0}: 50 \mathrm{mg} \mathrm{L}^{-1}$; volume of solution: $1.5 \mathrm{~L} ; \gamma-\mathrm{Al}_{2} \mathrm{O}_{3}: 2 \mathrm{~g} \mathrm{~L}^{-1}$.

of $21 \mathrm{mg} \mathrm{L}^{-1}$ after $5 \mathrm{~h}$. This decrease is due to its oxidation into carbon dioxide (Scheme 2). Concerning oxalic acid, a slight and steady increase of its concentration was noticed to reach a value of $6 \mathrm{mg} \mathrm{L}^{-1}$ after $5 \mathrm{~h}$ ozonation. Oxalic acid can be released from an opening of the aromatic ring and/or from the oxidation of dimers. The study of mass balance of the process (Table 3 ) indicated that after $1 \mathrm{~h}$ of reaction $0.41 \mathrm{mmol}$ of 2,4-DMP was transformed into $1 \mathrm{mmol} \mathrm{CH} \mathrm{COOH}_{3} 0.65 \mathrm{mmol} \mathrm{HCOOH}$ and $0.02 \mathrm{mmolHOOC}-\mathrm{COOH}$, which corresponds to the transformation of 1 molecule of 2,4-DMP into 2.4 molecules of $\mathrm{CH}_{3} \mathrm{COOH}, 1.6$ molecules of $\mathrm{HCOOH}$ and 0.05 molecule of $\mathrm{HOOC}-\mathrm{COOH}$. This result is close to the expected simplified direct ozonation of 2,4-DMP into acetic acid and formic acid

Table 3

Mass balance after 1 and $5 \mathrm{~h}$ of single ozonation and ozonation with $\gamma-\mathrm{Al}_{2} \mathrm{O}_{3}$ of 2,4-DMP.

\begin{tabular}{|c|c|c|c|c|}
\hline \multirow[b]{2}{*}{ Ozonation time } & \multicolumn{2}{|l|}{$\mathrm{O}_{3}$} & \multicolumn{2}{|c|}{$\mathrm{O}_{3}+\gamma-\mathrm{Al}_{2} \mathrm{O}_{3}$} \\
\hline & $1 \mathrm{~h}$ & $5 \mathrm{~h}$ & $1 \mathrm{~h}$ & $5 \mathrm{~h}$ \\
\hline $\mathrm{CH}_{3} \mathrm{COOH}\left(\mathrm{mmol} \mathrm{L}^{-1}\right)$ & 1 & 1 & 0.71 & 0.60 \\
\hline $\mathrm{HCOOH}\left(\mathrm{mmol} \mathrm{L}^{-1}\right)$ & 0.65 & 0.45 & 0.43 & 0.24 \\
\hline $\mathrm{HOOC}-\mathrm{COOH}\left(\mathrm{mmol} \mathrm{L}^{-1}\right)$ & 0.02 & 0.05 & 0.02 & 0.04 \\
\hline $\begin{array}{l}\text { Other by-products } \\
\left(\mathrm{mmol} \mathrm{CL}^{-1}\right)\end{array}$ & 0.43 & 0.27 & 0.73 & 0.25 \\
\hline Total by-products $\left(\mathrm{mmol} \mathrm{CL}^{-1}\right)$ & 3.12 & 2.82 & 2.62 & 1.77 \\
\hline Produced $\mathrm{CO}_{2}\left(\mathrm{mmolCL}^{-1}\right)$ & 0.16 & 0.46 & & \\
\hline $\begin{array}{l}\text { Produced } \mathrm{CO}_{2}+\text { adsorbated } \\
\text { by-products }\left(\mathrm{mmol} \mathrm{CL}^{-1}\right)\end{array}$ & & & 0.66 & 1.51 \\
\hline
\end{tabular}

Initial concentration 2,4-DMP: $50 \mathrm{mg} \mathrm{L}^{-1}\left(0.41 \mathrm{mmol} \mathrm{L}^{-1} ; 3.28 \mathrm{mmol} \mathrm{C} \mathrm{L}^{-1}\right)$.
(Scheme 2). The higher amount of acetic acid and the lower amount of formic acid were presumably due to the route implying dimerization of 2,4-DMP. The very low amount of oxalic acid could result from its reaction with the bihydroxylated by-product (product $\mathbf{1}$ in Scheme 2) as soon as it was produced. Taking into account TOC measurement and the initial amount of 2,4-DMP $\left(3.28 \mathrm{mmol} \mathrm{CL}^{-1}\right)$ it was possible to determine the amount of organics remaining in the solution and the level of mineralization (Table 3 ). After $5 \mathrm{~h}$ of single ozonation $2.82 \mathrm{mmol} \mathrm{CL}^{-1}$ remained in the solution composed at $90 \%$ of carboxylic acid and $10 \%$ of unknown by-products.

\subsubsection{Identification and quantification of carboxylic acids obtained during ozonation with $\gamma-\mathrm{Al}_{2} \mathrm{O}_{3}$}

During ozonation with $\gamma-\mathrm{Al}_{2} \mathrm{O}_{3}$ the same carboxylic acids as for single ozonation were identified and quantified: 1 molecule of 2,4DMP was converted into 1.7 molecules $\mathrm{CH}_{3} \mathrm{COOH}, 1.0$ molecule $\mathrm{HCOOH}$ and 0.05 molecule HOOC-COOH . Lower amounts of carboxylic acids were obtained for ozonation with $\gamma-\mathrm{Al}_{2} \mathrm{O}_{3}$ except for oxalic acid, which followed the same trend as for single ozonation (Fig. 5b). By allowing the generation of $\mathrm{HO} \bullet$ radicals $\gamma-\mathrm{Al}_{2} \mathrm{O}_{3}$ favors a different oxidation mechanism leading to less acetic acid and less formic acid. It could also be hypothesized that a non-reactive phenomenon occurred such as the adsorption of the carboxylic acids on the solid. Indeed the maximum concentration of acetic acid was reached after $75 \mathrm{~min}$ and then decreased, which cannot be due to the oxidation of acetic acid. Adsorption of carboxylic acids was thus investigated in the following paragraph. Concerning mass balance calculated from TOC and from the amount of carboxylic acids (Table 3 ) it was demonstrated that ozonation in presence of $\gamma-\mathrm{Al}_{2} \mathrm{O}_{3}$ generated after $1 \mathrm{~h}$ ozonation more by-products (other than carboxylic acids) due to the different mechanism pathway using $\mathrm{HO}^{\bullet}$ radicals with $0.73 \mathrm{mmolC}_{\text {by-product }} \mathrm{L}^{-1}$ after $1 \mathrm{~h}$ for ozonation with $\gamma-\mathrm{Al}_{2} \mathrm{O}_{3}$, whereas single ozonation produced only $0.43 \mathrm{mmol}_{\text {by-product }} \mathrm{L}^{-1}$. After $5 \mathrm{~h}$ ozonation the amount of by-products (other than carboxylic acids) decreased and reached a similar value of $\sim 0.26 \mathrm{mmol} \mathrm{C}_{\text {by-product }} \mathrm{L}^{-1}$ for both ozonation processes. However, the remaining by-products (other than carboxylic acids) resulting from $5 \mathrm{~h}$ ozonation with $\gamma-\mathrm{Al}_{2} \mathrm{O}_{3}$ are different from those obtained by single ozonation as they featured a higher level of oxidation state as previously demonstrated from AOSC measurements. Carboxylic acids represent $86 \%$ of the carbon remaining in the solution after $5 \mathrm{~h}$ ozonation. Ozonation with $\gamma$ $\mathrm{Al}_{2} \mathrm{O}_{3}$ allowed after $5 \mathrm{~h}$ to decrease the amount of organics in water from 3.28 to $1.77 \mathrm{mmol} \mathrm{CL}^{-1}$, whereas single ozonation reached only $2.82 \mathrm{mmol} \mathrm{CL}^{-1}$.

\subsection{Adsorption of carboxylic acids on $\gamma-\mathrm{Al}_{2} \mathrm{O}_{3}$}

\subsubsection{Adsorption isotherms of carboxylic acids on $\gamma-\mathrm{Al}_{2} \mathrm{O}_{3}$}

During 2,4-DMP oxidation, three carboxylic acids (acetic acid, formic acid and oxalic acid) have been identified and $\gamma-\mathrm{Al}_{2} \mathrm{O}_{3}$ adsorption properties towards these acids have been studied. The adsorption isotherms of the three carboxylic acids were carried out varying the acids concentrations from 5 to $400 \mathrm{mg} \mathrm{L}^{-1}$ (Fig. 6). The adsorption capacity of $\gamma-\mathrm{Al}_{2} \mathrm{O}_{3}$ became significant for equilibrium acid concentration higher than $25 \mathrm{mg} \mathrm{L}^{-1}$. For the highest acid concentration ( $400 \mathrm{mg} \mathrm{L}^{-1}$ ) an adsorption $20,23,35 \mathrm{mg} \mathrm{g}^{-1}$ (or $0.33,0.50$ and $0.38 \mathrm{mmol} \mathrm{g}^{-1}$ ) was obtained for acetic acid, formic acid and oxalic acid, respectively. During ozonation with $\gamma$ $\mathrm{Al}_{2} \mathrm{O}_{3}$ the maximum acid equilibrium concentrations were found after $1 \mathrm{~h}$ and corresponded to 43,20 and $2 \mathrm{mg} \mathrm{L}^{-1}$, for acetic acid, formic acid and oxalic acid, respectively. Considering the adsorption isotherms, an adsorption capacity on $\gamma-\mathrm{Al}_{2} \mathrm{O}_{3}$ of $3.4,3.7$ and $0.9 \mathrm{mg} \mathrm{g}^{-1}$ (or $0.06,0.08$ and $0.01 \mathrm{mmol} \mathrm{g}^{-1}$ ) for acetic acid, formic acid and oxalic acid, respectively, could be expected, which will contribute as $0.43 \mathrm{mmol} \mathrm{C} \mathrm{L}^{-1}$ in TOC removal. Adsorption of 


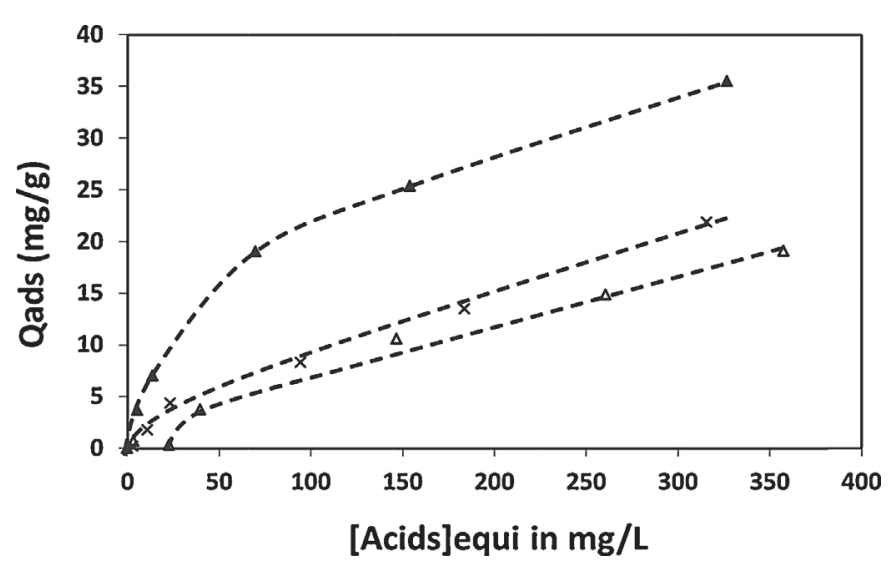

Fig. 6. Adsorption isotherms of acetic acid $(\Delta)$, formic acid $(x)$ and oxalic acid $(\boldsymbol{\Delta})$ onto $\gamma-\mathrm{Al}_{2} \mathrm{O}_{3}$ at $25^{\circ} \mathrm{C}$. [Acids] $]_{0}$ : from 5 to $400 \mathrm{mg} \mathrm{L}^{-1}$.

carboxylic will give a participation of $13 \%$ in the $46 \%$ TOC removal with $\gamma-\mathrm{Al}_{2} \mathrm{O}_{3}$, which is below to what was predicted (19\%) considering $11 \%$ of direct ozonation reaction (as for single ozonation) and $16 \%$ of radical reaction. Three possibilities could be considered: (1) other by-products could be adsorbed as dimethyl muconic acid, (2) the contribution of direct ozonation is higher (17\%) in presence of alumina due to ozone adsorption at the surface of the particles and (3) the amount of adsorbed carboxylic acids is higher in presence of ozone. Indeed during adsorption experiments of carboxylic acids on $\gamma-\mathrm{Al}_{2} \mathrm{O}_{3}$ the $\mathrm{pH}$ of the solution increased from 4.5 to 7.6. In this range of $\mathrm{pH}$ carboxylic acids are under carboxylates form $\left(\mathrm{CH}_{3} \mathrm{COO}^{-}, \mathrm{HCOO}^{-},{ }^{-} \mathrm{OOC}-\mathrm{COO}^{-}\right)$as $\mathrm{pH}$ is higher than the $\mathrm{pK}_{\mathrm{A}}$ of the acids $\left(\mathrm{pK}_{\mathrm{A}-\mathrm{CH}_{3} \mathrm{COOH}}=4.76, \mathrm{pK}_{\mathrm{A}-\mathrm{HCOOH}}=3.74, \mathrm{pK}_{\mathrm{A}-\mathrm{HOOC}-\mathrm{COOH}}=1.25\right.$ and 4.27). The adsorption of the carboxylates $\left(\mathrm{RCOO}^{-}\right)$on $\gamma-\mathrm{Al}_{2} \mathrm{O}_{3}$ occurs via a ligand exchange withAl-OH groups formingAl-O(CO)R groups and liberates $\mathrm{OH}^{-}$responsible for the increase of $\mathrm{pH}$. In ozonation with $\gamma-\mathrm{Al}_{2} \mathrm{O}_{3}$ the mechanism of adsorption is different as in contrary a decrease of $\mathrm{pH}$ from 4.5 to 2.5 was observed. At these $\mathrm{pH}$ carboxylic acids are under their protonated forms: $\mathrm{CH}_{3} \mathrm{COOH}, \mathrm{HCOOH}, \mathrm{HOOC}-\mathrm{COO}^{-}$, which could encountered for a different mechanism of adsorption and maybe a higher adsorption. Therefore, it is difficult from adsorption experiments to accurately estimate the amount of carboxylic acids adsorbed on $\gamma-\mathrm{Al}_{2} \mathrm{O}_{3}$ during ozonation.

\subsubsection{Identification of carboxylic acids adsorbed on $\gamma-\mathrm{Al}_{2} \mathrm{O}_{3}$ after ozonation by ${ }^{13} \mathrm{C} C P$ MAS NMR}

In order to confirm the adsorption of carboxylic acids on $\gamma-\mathrm{Al}_{2} \mathrm{O}_{3}$ in presence of ozone, solid state ${ }^{13} \mathrm{C} C \mathrm{CP}$ MAS NMR was performed on the materials after ozonation. ${ }^{13} \mathrm{C}$ NMR spectrum (Fig. S6) exhibited three major peaks with chemical shifts at 178, 164 and $21 \mathrm{ppm}$, confirming the adsorption of acetic acid, formic acid and/or oxalic acid at the surface of $\gamma-\mathrm{Al}_{2} \mathrm{O}_{3}$ [46,47]. It is difficult to assign the peak at $164 \mathrm{ppm}$ to either formic acid or oxalic acid. Indeed in liquid ${ }^{13} \mathrm{C}$ NMR, formic acid is identified by a peak (COO) at $165.8 \mathrm{ppm}$ and oxalic acid by a peak (COO) at $160.9 \mathrm{ppm}$. For acetic acid the two peaks at $178.1(\mathrm{COO})$ and $22\left(\mathrm{CH}_{3}\right)$ ppm were clearly identified. Additional peaks of lower intensity of unidentified products are present on the spectrum at 142,131, 81, 42 and $29 \mathrm{ppm}$. The peaks at 142, 131 and 29 could come from the adsorption of some dimethyl muconic acid, as muconic acid in solution presents three peaks at 166, 140 and $129 \mathrm{ppm}$ and the peak at $29 \mathrm{ppm}$ could come from the contribution of methyl groups. The peak at $42 \mathrm{ppm}$ could come from the adsorption of methyl malonic acid (Product $\mathbf{7}$ in Scheme 2), as malonic acid in solution presents two peaks at 178 and $49 \mathrm{ppm}$. However, it is very difficult to quantify each of these adsorbed products due to their very low amount on the material giving peaks just higher than the background noise on the spectrum.

3.6.3. Identification of carboxylates adsorbed on $\gamma-\mathrm{Al}_{2} \mathrm{O}_{3}$ after ozonation by FTIR

The adsorption of the carboxylic acids on $\gamma-\mathrm{Al}_{2} \mathrm{O}_{3}$ in presence of ozone was also confirmed by FTIR (Fig. S7). In comparison to FTIR spectrum of $\gamma-\mathrm{Al}_{2} \mathrm{O}_{3}$ before ozonation several additional vibrational bands of low intensity were found on the FTIR spectrum of $\gamma-\mathrm{Al}_{2} \mathrm{O}_{3}$ after ozonation after outgassing the sample at $150^{\circ} \mathrm{C}$ to remove the adsorbed water (large bending vibration of water at $1639 \mathrm{~cm}^{-1}$ ): at $1254,1312,1375,1392,1460,1505,1550,1572$, $1589,1615 \mathrm{~cm}^{-1}$. For each carboxylic acids four bands are expected: the symmetric and antisymmetric modes of $\mathrm{C}=\mathrm{O}$ streching are in the ranges $1625-1687$ and $1660-1740 \mathrm{~cm}^{-1}$, respectively, the C$\mathrm{O}-\mathrm{H}$ in-plane bending at $1395-1440 \mathrm{~cm}^{-1}$ and the $\mathrm{C}-\mathrm{O}$ stretch at $1315-1280 \mathrm{~cm}^{-1}$. However, no bands above $1625 \mathrm{~cm}^{-1}$ have been observed in the spectrum of $\gamma-\mathrm{Al}_{2} \mathrm{O}_{3}$ after ozonation revealing that carboxylic acids are under their carboxylates form. Indeed, for carboxylate salts only two vibrations for each salts are expected as $\mathrm{C}=\mathrm{O}$ andC-O bonds of the acid are replaced by two equivalentC-O "bondand-a half" bonds. These $\mathrm{CO}_{2}{ }^{-}$bonds interact out-of-phase and in-phase to give two bands. The antisymmetric $\mathrm{CO}_{2}$ stretch band is usually seen at $1540-1650 \mathrm{~cm}^{-1}$ and the symmetric $\mathrm{CO}_{2}$ stretch band is usually seen at $1360-1450 \mathrm{~cm}^{-1}$. Acetate salts bands are usually observed at $1400-1450$ and $1550-1600 \mathrm{~cm}^{-1}$, formate at 1360 and $1600 \mathrm{~cm}^{-1}$ and oxalate at 1320 and $1620 \mathrm{~cm}^{-1}$. Considering the vibrational bands observed in the spectrum of $\gamma-\mathrm{Al}_{2} \mathrm{O}_{3}$ after ozonation, the bands relative to carboxylates adsorbed on $\gamma-\mathrm{Al}_{2} \mathrm{O}_{3}$ surface could therefore be assigned as follows: for acetate bands at 1460 and $1550 \mathrm{~cm}^{-1}$; for formate bands at 1375 and $1589 \mathrm{~cm}^{-1}$; for oxalate bands at 1312 and $1615 \mathrm{~cm}^{-1}$. The remaining bands correspond to unidentified adsorbed products $(1254,1392,1505$, $1572 \mathrm{~cm}^{-1}$ ), which could result from the adsorption of other carboxylate by-products as dimethyl muconic acid, as assumed by ${ }^{13} \mathrm{C}$ NMR. Quantification of these products by FTIR was not possible as in too low amounts.

\subsection{Basic and acid sites of $\gamma-\mathrm{Al}_{2} \mathrm{O}_{3}$ before and after ozonation by FTIR}

$\gamma-\mathrm{Al}_{2} \mathrm{O}_{3}$ is an amphoteric solid with Lewis acid $\mathrm{AlOH}\left(\mathrm{H}^{+}\right)$sites and basicAl-OH sites (Scheme 3). The acidic properties of $\gamma-\mathrm{Al}_{2} \mathrm{O}_{3}$ before and after ozonation have been determined by FTIR after pyridine adsorption on dried materials (Fig. S8). FTIR/pyridine spectrum of $\gamma-\mathrm{Al}_{2} \mathrm{O}_{3}$ before ozonation featured no band at $1547 \mathrm{~cm}^{-1}$ characteristic of Brönsted acid site, and after ozonation a very weak band appeared, which disappeared at $100^{\circ} \mathrm{C}$ under vacuum, featuring very low amount of weak Brönsted sites. This could come from free $\mathrm{COOH}$ group on the surface of $\gamma-\mathrm{Al}_{2} \mathrm{O}_{3}$ after ozonation as in the case of oxalic acid adsorption. The band at $1596 \mathrm{~cm}^{-1}$ is relative to $\mathrm{H}$-bonding between $\mathrm{OH}$ surface groups and pyridine. This band disappeared after outgassing at $100^{\circ} \mathrm{C}$. Three similar intense bands at 1455,1496 and $1625 \mathrm{~cm}^{-1}$ were observed in FTIR/pyridine spectra of $\gamma-\mathrm{Al}_{2} \mathrm{O}_{3}$ before and after ozonation, which remained after outgassing at $500^{\circ} \mathrm{C}$. These bands are characteristic of strong Lewis acid sites. The Lewis acid sites of $\gamma-\mathrm{Al}_{2} \mathrm{O}_{3}$ were not modified during ozonation. If the Lewis acid sites of $\gamma-\mathrm{Al}_{2} \mathrm{O}_{3}$ participate to the ozonation process they are entirely regenerated during ozonation as already proposed in literature [8]. An example of simplified possible mechanism is given in Scheme 3. Furthermore, the acid sites of $\gamma-\mathrm{Al}_{2} \mathrm{O}_{3}$ are not affected by the adsorption of carboxylic acids, they are not the adsorption sites.

The basic properties of $\gamma-\mathrm{Al}_{2} \mathrm{O}_{3}$ before and after ozonation have been determined by FTIR after $\mathrm{CO}_{2}$ adsorption on dried materials (Fig. S9). For both materials, $\mathrm{CO}_{2}$ adsorption has revealed the 


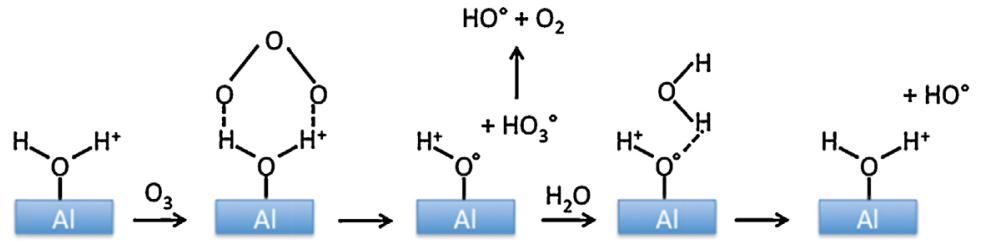

b

b $\mathrm{HO}^{\circ}+\mathrm{O}_{2}$

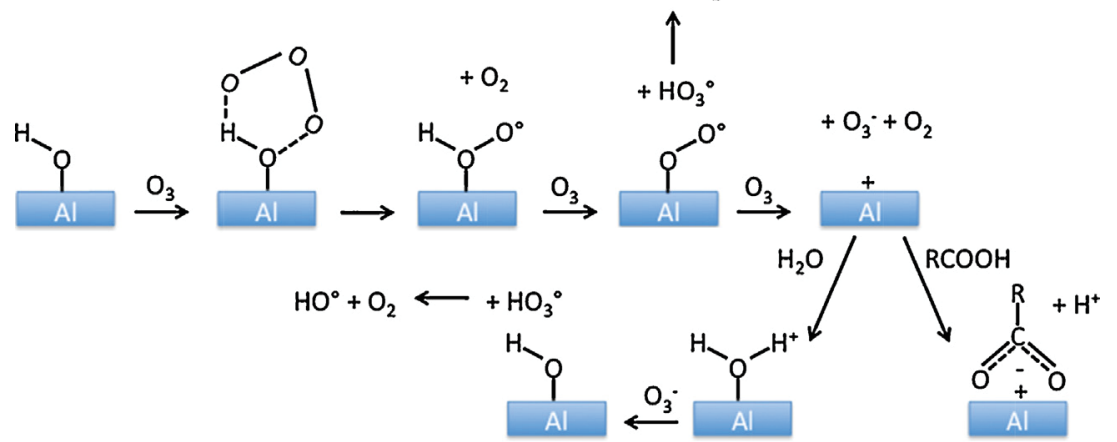

Scheme 3. Expected interaction of $\mathrm{O}_{3}$ with (a) acid and (b) basic sites of $\gamma$ - $\mathrm{Al}_{2} \mathrm{O}_{3}$ (scheme adapted and modified from Ref. [8]). (b) Hypothesis for adsorption mechanism of carboxylic acids with the basic sites of $\gamma-\mathrm{Al}_{2} \mathrm{O}_{3}$ during ozonation.

presence of $\mathrm{Al}^{3+}$ extra-framework species evidenced by a fine band at $2365 \mathrm{~cm}^{-1}$ of $\mathrm{CO}_{2}$ is linearly coordinated to these $\mathrm{Al}$ species. FTIR spectra of $\mathrm{CO}_{2}$ adsorbed on $\gamma-\mathrm{Al}_{2} \mathrm{O}_{3}$ before and after ozonation showed also similar four major peaks at 1231, 1482, 1644 and $1774 \mathrm{~cm}^{-1}$ characteristic of the formation of carbonates at the surface of the material due to the chemisorption of $\mathrm{CO}_{2}$ on the $\mathrm{Al}-\mathrm{OH}$ basic sites. Lower amount of carbonates were observed on $\gamma-\mathrm{Al}_{2} \mathrm{O}_{3}$ after ozonation. Furthermore, chemisorbed carbonates were desorbed at $250^{\circ} \mathrm{C}$ for $\gamma-\mathrm{Al}_{2} \mathrm{O}_{3}$ before ozonation featuring a medium force of the basic sites and at lower temperature $\left(200^{\circ} \mathrm{C}\right)$ on $\gamma-\mathrm{Al}_{2} \mathrm{O}_{3}$ after ozonation revealing a slightly lower force of the basic sites. Ozonation implied a decrease of the basicity of $\mathrm{Al}-\mathrm{OH}$ species in number and in force due most probably to carboxylates adsorption on the basic sites. An example of simplified possible mechanisms is given in Scheme 3 to explain the competition between $\mathrm{Al}-\mathrm{OH}$ as active site for catalytic ozonation and $\mathrm{Al}-\mathrm{OH}$ as adsorption sites for carboxylates. This hypothesis allows to explain the additional decrease of $\mathrm{pH}$ during ozonation with $\gamma$ $\mathrm{Al}_{2} \mathrm{O}_{3}$ due to the chemisorption of $\mathrm{RCOOH}$ on an intermediate site $\mathrm{Al}(+)$ (formed during ozonation), which liberates a proton to give an electrostatic interaction $\mathrm{RCOO}^{-}-\mathrm{Al}(+)$ and contributes to decrease the $\mathrm{pH}$ (Scheme 3). The amount of Al-OH species could not be calculated at $25^{\circ} \mathrm{C}$ due to the presence of water hiding FTIR bands of the $\mathrm{OH}$ region (3000-4000 $\mathrm{cm}^{-1}$ ). After outgassing the samples at $500^{\circ} \mathrm{C}$, which implies water removal but also carboxylates removal, similar FTIR spectra of Al-OH bands at 3793, 3774, 3730, 3689, $3675 \mathrm{~cm}^{-1}$ were observed for $\gamma-\mathrm{Al}_{2} \mathrm{O}_{3}$ before and after ozonation with an amount of $\mathrm{OH}$ groups $\sim 1.1 \mathrm{mmol} \mathrm{OH} \mathrm{g}^{-1}$ (Fig. S10). Basic $\mathrm{Al}-\mathrm{OH}$ sites are affected by carboxylates adsorption and their number decreased during ozonation, however the recovery of all $\mathrm{Al}-\mathrm{OH}$ groups after outgassing suggests a possible regeneration of $\gamma-\mathrm{Al}_{2} \mathrm{O}_{3}$ by calcination at $500^{\circ} \mathrm{C}$.

\subsection{Reuse and regeneration of $\gamma-\mathrm{Al}_{2} \mathrm{O}_{3}$}

\subsubsection{Reuse of $\gamma-\mathrm{Al}_{2} \mathrm{O}_{3}$ in successive ozonation reactions}

To establish the durability of $\gamma-\mathrm{Al}_{2} \mathrm{O}_{3}$ during ozonation, the material has been reused in 10 successive runs with a higher amount of solid $\left(5 \mathrm{~g} \mathrm{~L}^{-1}\right)$ and a higher amount of entering $\mathrm{O}_{3}$ $\left(5 \mathrm{~g} \mathrm{Nm}^{-3}\right.$ produced from $\left.\mathrm{O}_{2}\right)$. This slightly harder condition of ozonation allowed for the first run to reach a higher level of TOC removal with $71 \%$ after $8 \mathrm{~h}$ with $\gamma-\mathrm{Al}_{2} \mathrm{O}_{3}$, whereas for single ozonation TOC removal was only $30 \%$ (Fig. 7). Then a series of 10 ozonation runs was performed using the same $\gamma-\mathrm{Al}_{2} \mathrm{O}_{3}$ sample, in order to assess the stability of the material (Fig. 7). Each run lasted about $8 \mathrm{~h}$ and $\gamma-\mathrm{Al}_{2} \mathrm{O}_{3}$ was reused without any regeneration or specific treatment. Millimetric $\gamma-\mathrm{Al}_{2} \mathrm{O}_{3}$ particles were put in a perforated basket easy to immerge in the solution and easy to remove and to place in another batch of effluent. TOC removal clearly progressively decreased during the successive runs with $\gamma-\mathrm{Al}_{2} \mathrm{O}_{3}$. After $7-10$ runs with $\gamma-\mathrm{Al}_{2} \mathrm{O}_{3}$ TOC removal was quite reproducible with $40 \%$ TOC removal, which remained higher than single ozonation (30\% TOC removal). The decrease of TOC removal with $\gamma-\mathrm{Al}_{2} \mathrm{O}_{3}$ is due to the decrease of the amount of basic Al-OH sites by irreversible chemisorption of carboxylates (Scheme 3 ). If for each run $0.15 \mathrm{mmol}$ of carboxylates per gram of $\gamma-\mathrm{Al}_{2} \mathrm{O}_{3}$ are chemisorbed on $\mathrm{Al}-\mathrm{OH}$ (as found in Section 3.6.1), seven runs will be enough to eliminate all Al-OH groups of $\gamma-\mathrm{Al}_{2} \mathrm{O}_{3}\left(1.1 \mathrm{mmol} \mathrm{OH} \mathrm{g}{ }^{-1}\right)$, which is consistent with the result obtained in this reuse study.

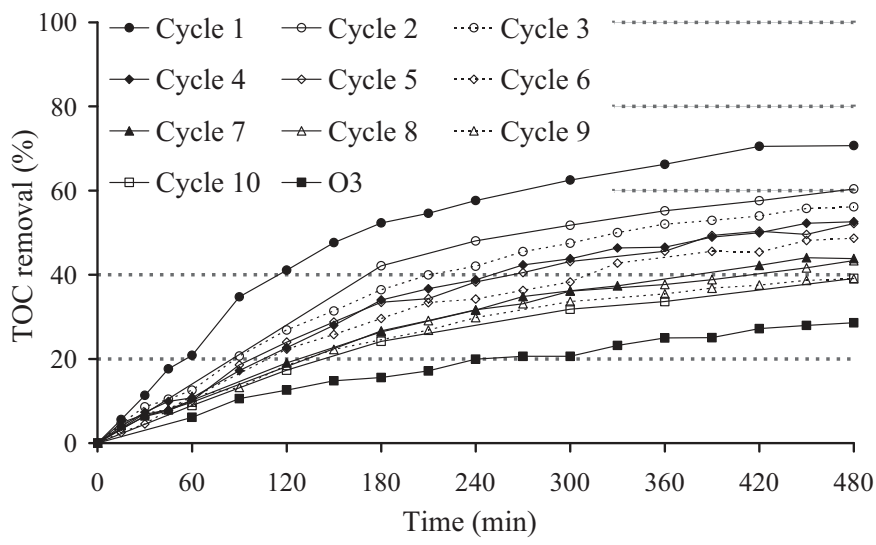

Fig. 7. TOC removal during single ozonation ( $\mathbf{\square})$ and during a series of 10 successive ozone $/ \gamma-\mathrm{Al}_{2} \mathrm{O}_{3}$ coupled treatment runs using the same solid without regeneration. First run $(\bullet)$, fifth run $(\diamond)$ and tenth run $(\bigcirc)$. Temperature: $25^{\circ} \mathrm{C} ; \mathrm{O}_{3}$ flow rate: $30 \mathrm{Lh}^{-1} ;\left[\mathrm{O}_{3}\right]_{\text {Inlet }}: 5 \mathrm{~g} \mathrm{Nm}^{-3}$; [2,4-DMP $]_{0}: 50 \mathrm{mg} \mathrm{L}^{-1}$; volume of solution: $2 \mathrm{~L}$; $\gamma-\mathrm{Al}_{2} \mathrm{O}_{3}: 5 \mathrm{~g} \mathrm{~L}^{-1}$. 


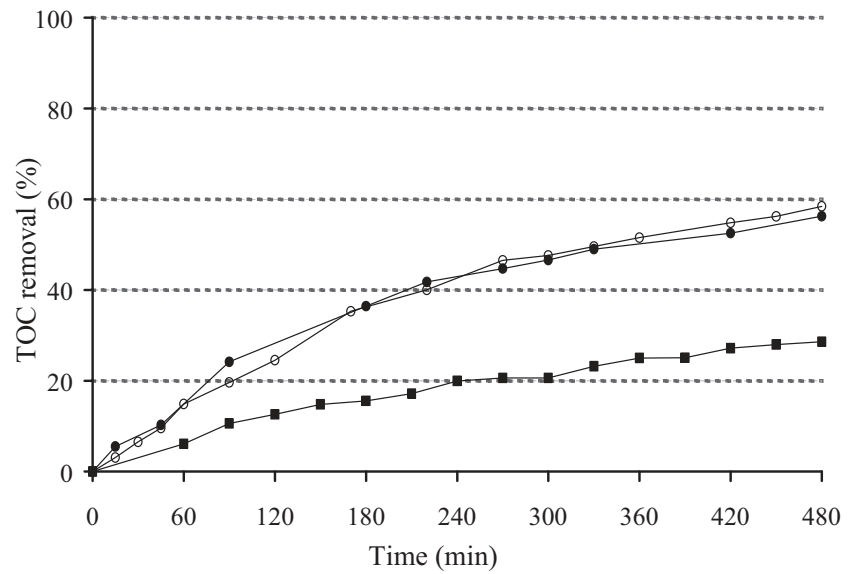

Fig. 8. TOC removal during single ozonation ( $\square$ ) and during ozone $/ \gamma-\mathrm{Al}_{2} \mathrm{O}_{3}$ coupled treatment using a fresh sample of alumina $(\bullet)$ and a thermally regenerated sample of alumina $(\bigcirc)$. Temperature: $25^{\circ} \mathrm{C} ; \mathrm{O}_{3}$ flow rate: $30 \mathrm{Lh}^{-1} ;\left[\mathrm{O}_{3}\right]_{\text {Inlet }}: 5 \mathrm{~g} \mathrm{Nm}^{-3} ;[2,4-$ $\mathrm{DMP}]_{0}$ : $50 \mathrm{mg} \mathrm{L}^{-1}$; volume of solution: $2 \mathrm{~L} ; \gamma-\mathrm{Al}_{2} \mathrm{O}_{3}: 1.85 \mathrm{~g} \mathrm{~L}^{-1}$.

The remaining stable activity of $\gamma-\mathrm{Al}_{2} \mathrm{O}_{3}$ after $7-10$ runs, which is $10 \%$ higher than single ozonation is due either to reversible catalytic activity of Lewis sites of $\gamma-\mathrm{Al}_{2} \mathrm{O}_{3}$ or to a higher efficiency of direct $\mathrm{O}_{3}$ reaction at the solid surface. As for the previous study $16 \%$ TOC removal were assigned to radical reaction (Section 3.4), radicals are produced either by acid sites or acidic sites (Scheme 3), it seems that basic sites are also involved in the catalytic activity of $\gamma-\mathrm{Al}_{2} \mathrm{O}_{3}$. Basic sites of $\gamma-\mathrm{Al}_{2} \mathrm{O}_{3}$ act in TOC removal as carboxylic acids adsorbents and also as basic catalytic sites, which are lost at each carboxylate adsorption.

\subsubsection{Regeneration of $\gamma-\mathrm{Al}_{2} \mathrm{O}_{3}$ after ozonation}

After 10 runs of ozonation ( $80 \mathrm{~h}$ ozonation), $\gamma-\mathrm{Al}_{2} \mathrm{O}_{3}$ was removed from the solution, dried at $120^{\circ} \mathrm{C}$ during $20 \mathrm{~min}$ and calcined at $500^{\circ} \mathrm{C}$ during $6 \mathrm{~h}$. A part of the resulting material $\left(1.85 \mathrm{~g} \mathrm{~L}^{-1}\right)$ was then used in a new ozonation experiment and its performance was compared to the same amount of a fresh $\gamma-\mathrm{Al}_{2} \mathrm{O}_{3}$ sample. The thermally regenerated $\gamma-\mathrm{Al}_{2} \mathrm{O}_{3}$ showed a similar efficiency of the new $\gamma-\mathrm{Al}_{2} \mathrm{O}_{3}$ with $60 \%$ TOC removal after $8 \mathrm{~h}$ (Fig. 8). As observed earlier by FTIR (Section 3.7), a calcination at $500^{\circ} \mathrm{C}$ allowed to remove adsorbed carboxylates and to recover all basic Al-OH groups of $\gamma-\mathrm{Al}_{2} \mathrm{O}_{3}$. Therefore, a calcination at $500^{\circ} \mathrm{C}$ allows to regenerate and reuse this catalyst without any loss of performances.

\subsection{Ozonation of a synthetic petroleum effluent}

\subsubsection{Ozonation of a synthetic petroleum effluent without any additive}

A synthetic petrochemical effluent containing various petrochemicals was treated with $\gamma-\mathrm{Al}_{2} \mathrm{O}_{3}$. This experiment was performed in a third pilot plant scale reactor described elsewhere [28]. The complex synthetic effluent was a mixture of several aromatic hydrocarbons and associated acids: phenol, acetic acid, naphtenic acid, pyrene, naphtalene with initial concentration of $200,200,25,0.05,0.95 \mathrm{mg} \mathrm{L}^{-1}$, respectively, corresponding to TOC $=230 \mathrm{mg} \mathrm{L}^{-1}$. With $\gamma-\mathrm{Al}_{2} \mathrm{O}_{3}$ TOC removal was much faster than for single ozonation during the first $50 \mathrm{~min}$ and then stopped and remained at 50\% equivalent to single ozonation (Fig. 9). In the synthetic effluent a large amount $\left(200 \mathrm{mg} \mathrm{L}^{-1}\right)$ of acetic acid was added, which blocked Al-OH basic sites of $\gamma-\mathrm{Al}_{2} \mathrm{O}_{3}$ from the beginning of the process. Considering the adsorption isotherm (Fig. 6) a concentration of acetic acid of $200 \mathrm{mg} \mathrm{L}^{-1}$ will correspond to $12 \mathrm{mgg}^{-1}\left(0.20 \mathrm{mmolg}^{-1}\right)$ of acetate adsorbed on the
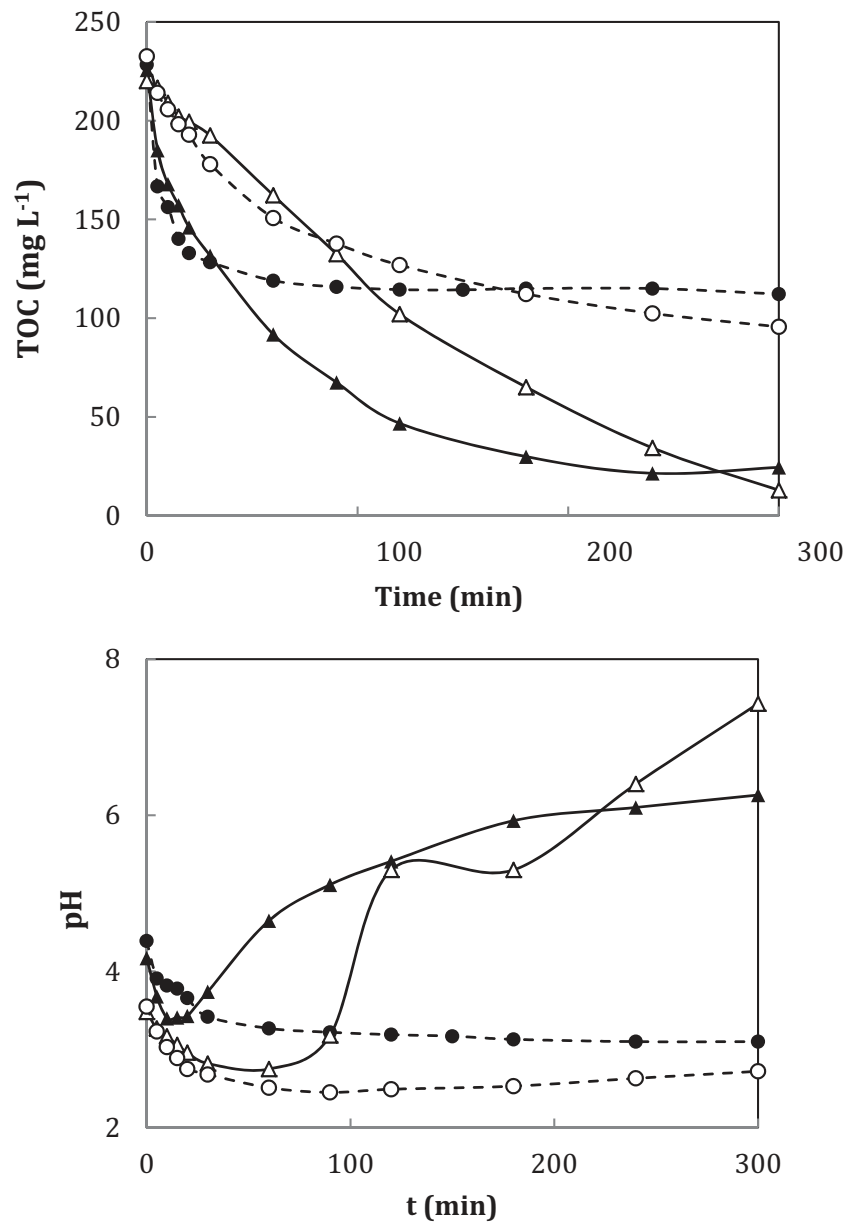

Fig. 9. TOC and $\mathrm{pH}$ evolution during single ozonation (open symbols) and during ozonation with $\gamma-\mathrm{Al}_{2} \mathrm{O}_{3}$ (plain symbols) without (circles) and with (triangles) $\mathrm{NaCl}$ $50 \mathrm{~g} \mathrm{~L}^{-1}$ of a synthetic petrochemical effluent containing various petrochemicals: $200 \mathrm{mg} \mathrm{L}^{-1}$ phenol, $200 \mathrm{mg} \mathrm{L}^{-1}$ acetic acid, $25 \mathrm{mg} \mathrm{L}^{-1}$ naphtenic acid, $0.05 \mathrm{mg} \mathrm{L}^{-1}$ pyrene, $0.95 \mathrm{mg} \mathrm{L}^{-1}$ naphtalene. Temperature: $35^{\circ} \mathrm{C} ; \mathrm{O}_{3}$ flow rate: $24 \mathrm{~L} \mathrm{~h}^{-1} ;\left[\mathrm{O}_{3}\right]_{\text {Inlet }}$ : $5 \mathrm{~g} \mathrm{Nm}^{-3}$; [TOC $]_{0}: 250 \mathrm{mg} \mathrm{L}^{-1}$; volume of solution: $1.5 \mathrm{~L} ; \gamma-\mathrm{Al}_{2} \mathrm{O}_{3}: 2 \mathrm{~g} \mathrm{~L}^{-1}$.

solid. A large amount of phenol (200 $\left.\mathrm{mg} \mathrm{L}^{-1}, 2.1 \mathrm{mmol} \mathrm{L}^{-1}\right)$ was also added and if we consider a similar mechanism as for 2,4DMP (Section 3.5.4) $1 \mathrm{~mol}$ of phenol will produce $1.7 \mathrm{~mol}$ acetic acid, $1 \mathrm{~mol}$ formic acid and $0.05 \mathrm{~mol}$ oxalic acid. This will correspond to a production of $216 \mathrm{mg} \mathrm{L}^{-1}$ of acetic acid, $100 \mathrm{mg} \mathrm{L}^{-1}$ formic acid and $9 \mathrm{mg} \mathrm{L}^{-1}$ oxalic acid and therefore an adsorption capacity (calculated from the adsorption isotherms in Fig. 6) on $\gamma-\mathrm{Al}_{2} \mathrm{O}_{3}$ of $13 \mathrm{mg} \mathrm{g}^{-1}\left(0.22 \mathrm{mmol} \mathrm{g}^{-1}\right), 10 \mathrm{mg} \mathrm{g}^{-1}\left(0.21 \mathrm{mmol} \mathrm{g}^{-1}\right)$, $6 \mathrm{mg} \mathrm{g}^{-1}\left(0.07 \mathrm{mmol} \mathrm{g}^{-1}\right)$ for each acid, respectively. The total of expected carboxylates adsorbed on the solid will be therefore at least $0.7 \mathrm{mmol} \mathrm{g}^{-1}$, which means that for only two molecules (acetic acid and phenol) already $\sim 65 \%$ of Al-OH basic sites will be rapidly blocked. The stopover of the reaction after $50 \mathrm{~min}$ with $\gamma-\mathrm{Al}_{2} \mathrm{O}_{3}$ is therefore due to the total obstruction of $\mathrm{Al}-\mathrm{OH}$ basic sites by adsorbed carboxylates. For single ozonation a slightly higher TOC removal is obtained after $300 \mathrm{~min}$ ( $58 \%$ TOC removal). The fact that $\gamma-\mathrm{Al}_{2} \mathrm{O}_{3}$ presents no better activity than single ozonation when all of the basic sites are blocked let suppose that the Lewis acid sites of $\gamma-\mathrm{Al}_{2} \mathrm{O}_{3}$ do not participate to the ozonation process. We have previously observed that Lewis acid sites were not affected during ozonation (Section 3.7). We therefore proposed that the catalytic activity of oxides in water ozonation is due principally to the basic sites (M-OH) of the materials (Scheme 3 ). The Lewis acid sites previously demonstrated as responsible for catalytic ozonation in 
gaseous phase $[48,49]$ cannot participate to the reaction in water, as these sites are surely blocked by water molecules that $\mathrm{O}_{3}$ cannot displace.

\subsubsection{Ozonation of a synthetic petroleum effluent in presence of} $\mathrm{NaCl}$ and toxicity tests

The effect of $\mathrm{NaCl}$ in ozonation processes is very important as some wastewater contains some salts as $\mathrm{NaCl}$, which can be present in high concentration level in tannery and dye manufacturing wastewater, for instance, and also in lower amount in produced water from off-shore oil extraction. An excess of $\mathrm{NaCl}$ $\left(50 \mathrm{~g} \mathrm{~L}^{-1}\right)$ was added to the ozonation process whereas in seawater $\mathrm{NaCl}$ concentration is around $10 \mathrm{~g} \mathrm{~L}^{-1}$. Adding $\mathrm{NaCl}$ to the solution containing various chemicals (phenol, acetic acid, naphtenic acid, pyrene, naphtalene) led to an increase in TOC removal for both processes single ozonation and ozonation with $\gamma-\mathrm{Al}_{2} \mathrm{O}_{3}$ (Fig. 9). The inverse phenomenon was observed previously in ozonation of 2,4DMP with basic Na-LTA zeolites with the same amount of $\mathrm{NaCl}$ [18]. It was observed that $\mathrm{Cl}^{-}$ions were scavenging $\mathrm{HO}^{\bullet}$ radicals similarly as $t$ - $\mathrm{BuOH}$ for a $\mathrm{pH}$ solution varying from $\mathrm{pH} 5$ to 7 and no effect (or a slight negative effect) was observed for the single ozonation [18]. It was showed in literature that the efficiency of chloride ions as $\mathrm{HO}^{\bullet}$ scavenger increases by a factor of 100 then $\mathrm{pH}$ decreases from 6 to 3 and then the concentration of $\mathrm{NaCl}$ increases from 1.5 to $73 \mathrm{~g} \mathrm{~L}^{-1}$ [50]. For low salinity water $\left(<1.5 \mathrm{~g} \mathrm{~L}^{-1}\right)$ and at $\mathrm{pH} 5$ no effect of chloride ions was observed. For concentration of $\mathrm{NaCl}>75$, 50 and $10 \mathrm{~g} \mathrm{~L}^{-1} 75,70$ and $25 \%$ of $\mathrm{HO}^{\bullet}$ were removed, respectively. As in the present study the salinity of the solution is high $\left(50 \mathrm{~g} \mathrm{~L}^{-1}\right)$ and the $\mathrm{pH}$ of the solution is acidic $(4>\mathrm{pH}>3)$ chloride ions should present a very strong scavenging effect on $\mathrm{HO}^{\bullet}$ radicals produced during ozonation with $\gamma-\mathrm{Al}_{2} \mathrm{O}_{3}$. The equations corresponding to the reaction of chloride ions with $\mathrm{HO}^{\bullet}$ are the following [50]:

$\mathrm{HO}^{\bullet}+\mathrm{Cl}^{-} \rightarrow \mathrm{HOCl}^{-\bullet}$

$\mathrm{HOCl}^{-\bullet}+\mathrm{H}+\rightarrow \mathrm{Cl}^{\bullet}+\mathrm{H}_{2} \mathrm{O} \quad$ pK $=7.2$

The first reaction is fast and the second reaction is five times more rapid than the first one. At $\mathrm{pH}<7.2 \mathrm{Cl}{ }^{\circ}$ is the dominant species. Although $\mathrm{HO}^{\bullet}$ should be seriously scavenged by $\mathrm{Cl}^{-}$a remarkable positive effect of $\mathrm{NaCl}$ was noticed with TOC removal reaching $90 \%$ against $50 \%$ without $\mathrm{NaCl}$. This high level of TOC removal indicates that acetic acid has been mineralized during the ozonation process with $\mathrm{NaCl}$. $\mathrm{NaCl}$ avoid carboxylates to block the basic sites of $\gamma$ $\mathrm{Al}_{2} \mathrm{O}_{3}$ with presumably sodium cations interacting with carboxylic acids to give the corresponding salts. Considering single ozonation the only difference with our previous study about ozonation in presence of zeolites and $\mathrm{NaCl}$ [18] is the solution composition and mainly the presence of polycyclic aromatic hydrocarbons (PAH). Ozone in presence of chloride anions in acidic aqueous medium reacts following the proposed equations $[51,52]$ :

$$
\mathrm{O}_{3}+\mathrm{Cl}^{-} \rightarrow \mathrm{O}_{2}+\mathrm{ClO}^{-}
$$

(ratedeterminingreaction, veryslowreaction)

$$
2 \mathrm{H}^{+}+\mathrm{Cl}^{-}+\mathrm{ClO}^{-} \rightarrow \mathrm{Cl}_{2}+\mathrm{H}_{2} \mathrm{O}
$$

$\mathrm{Cl}_{2}$ has been observed as the main and only product resulting from $\mathrm{O}_{3}$ decomposition in presence of $\mathrm{NaCl}$ [52] although $\mathrm{Cl}_{2}$ in water is in equilibrium with other products [53]:

$\mathrm{Cl}_{2}+\mathrm{H}_{2} \mathrm{O} \rightarrow \mathrm{HOCl}+\mathrm{H}^{+}+\mathrm{Cl}^{-} \quad \mathrm{pK}_{1}=3.3$

$$
\mathrm{HOCl} \rightarrow \mathrm{OCl}^{-}+\mathrm{H}^{+} \quad \mathrm{pK}_{2}=7.5
$$

For $\mathrm{pH}<3.3 \mathrm{Cl}_{2}$ will be the main species, for $3.3<\mathrm{pH}<7.5$ $\mathrm{HOCl}$ and for $\mathrm{pH}>7.5 \mathrm{OCl}^{-}$[53]. At low initial $\mathrm{pH}(\mathrm{pH}<2.5)$ chlorine species are able to degrade efficiently some carboxylic acids (oxalic $\gg$ citric $>$ maleic acids) leading to a $\mathrm{pH}$ increase from 2.5 to 9 [53]. However, acetic acid is barely decomposed except if a new source of $\mathrm{HO}^{\bullet}$ radical is produced as for instance by UV irradiation [53]. However, under UV, generally an intermediate product as $\mathrm{H}_{2} \mathrm{O}_{2}$ is produced as for $\mathrm{O}_{3} / \mathrm{UV}$ [50]:

$\mathrm{O}_{3}+\mathrm{H}_{2} \mathrm{O} \rightarrow \mathrm{H}_{2} \mathrm{O}_{2} \quad$ UVlightat254 nm(lowpressurelamp)

$\mathrm{O}_{3}+\mathrm{H}_{2} \mathrm{O}_{2} \rightarrow 2 \mathrm{HO}^{\bullet}+3 \mathrm{O}_{2}$

As in our study $\mathrm{HO}^{\bullet}$ are most probably highly scavenged by $\mathrm{Cl}^{-}$, therefore we propose that $\mathrm{H}_{2} \mathrm{O}_{2}$ could be also produced as an intermediary product during ozonation of PAH in presence of $\mathrm{NaCl}$ to explain the higher oxidation level of single ozonation and the mineralization of acetic acid. Indeed $\mathrm{H}_{2} \mathrm{O}_{2}$ could react with acetic acid to give peracetic acid, which is a powerful oxidant. We suggest that $\mathrm{PAH}$ compounds react with $\mathrm{Cl}^{\bullet}$ or $\mathrm{Cl}_{2}$ to produce $\mathrm{H}_{2} \mathrm{O}_{2}$ and $\mathrm{HO}^{\bullet}$. Indeed PAHs are known to decompose in water by chlorine [55] and give the corresponding quinones [56]. Industrially $\mathrm{H}_{2} \mathrm{O}_{2}$ is produced from the oxidation of dihydroxyanthracene by $\mathrm{O}_{2}$ giving anthraquinone and $\mathrm{H}_{2} \mathrm{O}_{2}$. For ozonation in presence of $\mathrm{NaCl}$ and $\mathrm{PAH}$ we suggest the formation of an intermediate dihydroxypolyaromatic compounds giving corresponding quinone and $\mathrm{H}_{2} \mathrm{O}_{2}$. It has been demonstrated that pyrene with chlorine decomposes into pyrene-4,5-dione and 1-chloropyrene by both oxidation and chlorine-substitution reactions, respectively [57]. Authors evidenced that pyrene decomposition was associated with the formation of other reactive species than chlorine and they suggest the formation of $\mathrm{HO}^{\bullet}$ radicals. These reactive species produced during pyrene decomposition in chlorination have not been identified but are reacting with ethanol. As we previously showed that acetic acid could not decomposed by $\mathrm{HO}^{\bullet}$ radicals, we suggest that one of these reactive species could be $\mathrm{H}_{2} \mathrm{O}_{2}$. The increase of TOC removal in the presence of $\mathrm{NaCl}$ was accompanied by the increase of the pH of the solution (Fig. 9) from 3.5 to 6 with $\gamma-\mathrm{Al}_{2} \mathrm{O}_{3}$ after $25 \mathrm{~min}$ revealing the degradation of the sodium carboxylates liberating $\mathrm{CO}_{2}$ and $\mathrm{HO}^{-}$. For single ozonation, the $\mathrm{pH}$ of the solution increased from 3 to 7 after $100 \mathrm{~min}$ due to the degradation of the carboxylic acids. The faster efficiency observed with $\gamma-\mathrm{Al}_{2} \mathrm{O}_{3}$ is most probably due to the faster formation of $\mathrm{Cl}^{\bullet}$ from $\mathrm{HO}^{\bullet}$ in comparison to the slow formation of $\mathrm{Cl}_{2}$ from $\mathrm{O}_{3}$. After $5 \mathrm{~h}$ the two processes have equivalent TOC removal (90\%).

It was previously demonstrated in literature that the toxicity of a solution containing pollutants increased when single ozonation was performed in presence of $\mathrm{NaCl}$ [54]. Toxicity tests were therefore performed for ozonation with $\gamma-\mathrm{Al}_{2} \mathrm{O}_{3}$ in presence of $\mathrm{NaCl}$ using two non-standardized toxkits named ARTOXKIT and ROTOXKIT exploiting two different seawater organisms Artemia franciscana and Brachionus calyciflorus, respectively. The toxicity tests were performed after $\mathrm{pH}$ adjustment at $\mathrm{pH} 7$ of the synthetic effluent treated after 150 and 300 min of ozonation with $\gamma-\mathrm{Al}_{2} \mathrm{O}_{3}$. The efficiency of the process was assessed by the effluent concentration able to induce $50 \%$ of mortality of the species after $24 \mathrm{~h}$ of exposal to the aqueous solution ( $\mathrm{LC}_{50} 24 \mathrm{~h}$ ). The results were expressed in toxic unit: Equitox $\mathrm{m}^{-3}=100 / \mathrm{LC}_{50} 24 \mathrm{~h}$ (Table 4 ). After 150 min of ozonation with $\gamma-\mathrm{Al}_{2} \mathrm{O}_{3}$ the toxicity level of the solution increased revealing that the first by-products produced during ozonation are more toxic than the initial pollutants. After 300 min of ozonation with $\gamma-\mathrm{Al}_{2} \mathrm{O}_{3}$ the toxicity level of the solution decreased. The synthetic effluent, which was initially considered as slightly toxic, became non-toxic for at least one seawater organism. 
Table 4

Percentage of TOC removal and toxicity index of the synthetic petrochemical effluent (phenol, acetic acid, naphthenic acid, pyrene, naphtalene) after ozonation with $\gamma$ - $\mathrm{Al}_{2} \mathrm{O}_{3}$ after 150 and 300 min treatment.

\begin{tabular}{lcclc}
\hline & TOC removal $(\%)$ & ARTOXKIT (toxic unit $^{\mathrm{a}}$ ) & ROTOXKIT (toxic unit $^{\mathrm{a}}$ ) \\
\hline Initial solution & 0 & 5.2 & 5.9 & Toxicity \\
$\mathrm{O}_{3} / \gamma-\mathrm{Al}_{2} \mathrm{O}_{3}(150 \mathrm{~min})$ & 82 & 10.1 & 8.4 & Slightly toxic \\
$\mathrm{O}_{3} / \gamma-\mathrm{Al}_{2} \mathrm{O}_{3}(300 \mathrm{~min})$ & 89 & 2.6 & 5.0 & Slightly toxic \\
\hline
\end{tabular}

a Toxic unit: non-toxic $<3 ; 3<$ slightly toxic $<10 ; 10<$ toxic $<50 ; 50<$ very toxic $<100$; extremely toxic $>100$. Temperature: $35^{\circ} \mathrm{C} ; \mathrm{O}_{3}$ flow rate: $24 \mathrm{Lh}^{-1}$; $\left[\mathrm{O}_{3}\right]_{\text {Inlet }}$ : $5 \mathrm{~g} \mathrm{Nm}{ }^{-3}$; $\mathrm{TOC}_{\text {Initial }}=230 \mathrm{mg} \mathrm{L}^{-1}$; volume of solution: $1.5 \mathrm{~L} ; \gamma-\mathrm{Al}_{2} \mathrm{O}_{3}: 2 \mathrm{~g} \mathrm{~L}^{-1} ; \mathrm{NaCl}: 50 \mathrm{~g} \mathrm{~L}^{-1}$.

Catalytic ozonation in presence of $\mathrm{NaCl}$ with $\gamma-\mathrm{Al}_{2} \mathrm{O}_{3}$ allowed to decrease the toxicity of the petrochemical effluent.

\section{Conclusion}

The effect of $\gamma-\mathrm{Al}_{2} \mathrm{O}_{3}$ during ozonation for 2,4-DMP removal was investigated through different experiments. It appeared clearly that the material allowed increasing the oxidation efficiency of the initial pollutant in comparison to single ozonation. The beneficial effect of $\gamma-\mathrm{Al}_{2} \mathrm{O}_{3}$ was linked to two phenomena: its adsorption capacity for carboxylic acids by-products (acetic acid, formic acid and oxalic acid) and its ability to generate $\bullet \mathrm{OH}$ radicals. The identification of different by-products during 2,4-DMP ozonation confirmed that both mechanisms of direct $\mathrm{O}_{3}$ reaction and radical type reaction coexisted during ozonation with $\gamma-\mathrm{Al}_{2} \mathrm{O}_{3}$, in contrary to single ozonation, which is mainly governed by direct $\mathrm{O}_{3}$ reaction. Radical type reaction for ozonation with $\gamma-\mathrm{Al}_{2} \mathrm{O}_{3}$ produced initially more by-products (other than acetic, formic and oxalic acids) than single ozonation leading at the end to less carboxylic acids formation. After $5 \mathrm{~h}$ ozonation similar amount of by-products (other than carboxylic acids) were found for both processes, but final byproducts were more oxidized with $\gamma-\mathrm{Al}_{2} \mathrm{O}_{3}$ than those resulting of single ozonation. Cumulative adsorption of carboxylic acids on the basic $\mathrm{Al}-\mathrm{OH}$ sites of $\gamma-\mathrm{Al}_{2} \mathrm{O}_{3}$ resulted in a progressive decrease of the TOC removal during successive runs of ozonation until all $\mathrm{Al}-\mathrm{OH}$ groups were blocked by carboxylates. Lewis acid sites of $\gamma-\mathrm{Al}_{2} \mathrm{O}_{3}$ were not affected during ozonation. A complete regeneration of Al$\mathrm{OH}$ basic sites was obtained by thermal treatment at $500{ }^{\circ} \mathrm{C}$ without altering the properties of the solid. Finally, $\gamma-\mathrm{Al}_{2} \mathrm{O}_{3}$ was used to treat a synthetic petrochemical effluent containing different pollutants (phenol, naphtenic acid, pyrene, naphtalene) and a large amount of acetic acid. TOC removal with $\gamma-\mathrm{Al}_{2} \mathrm{O}_{3}$ was very fast in the first hour of ozonation, much faster than single ozonation, and then stopped due to the inhibition of all Al-OH groups by carboxylates. A similar activity as single ozonation was then obtained with $50 \%$ TOC removal. This result allows us to propose that only $\mathrm{Al}-\mathrm{OH}$ basic sites are involved in catalytic ozonation in water. By adding $\mathrm{NaCl}$ to the ozonation processes remarkable higher TOC removals were reached for single ozonation and for ozonation with $\gamma-\mathrm{Al}_{2} \mathrm{O}_{3}$ with $90 \%$ TOC after $5 \mathrm{~h}$. Two antagonism mechanisms occur with $\gamma-\mathrm{Al}_{2} \mathrm{O}_{3}$ : sodium cations prevent the adsorption of carboxylates on the basic sites of $\gamma-\mathrm{Al}_{2} \mathrm{O}_{3}$ by forming preferentially sodium carboxylates in solution, while chloride ions are strong ${ }^{\circ} \mathrm{OH}$ scavengers especially in the conditions of the study (low $\mathrm{pH}$ and high $\mathrm{NaCl}$ concentration). The higher TOC removal is concomitant with the increase of $\mathrm{pH}$ due presumably to the degradation of carboxylates liberating hydroxyl ions. The reaction is faster with $\gamma-\mathrm{Al}_{2} \mathrm{O}_{3}$ in comparison to single ozonation due to different mechanism pathways between chloride ions with ${ }^{\bullet} \mathrm{OH}$ and with $\mathrm{O}_{3}$, respectively. The enhancement of the mineralization of the solution is also conjointly most probably induced by the formation of $\mathrm{H}_{2} \mathrm{O}_{2}$ resulting from oxidation reactions between polycyclic aromatic hydrocarbon (PAH) and ${ }^{\bullet} \mathrm{Cl}$ or $\mathrm{Cl}_{2}$ for ozonation with $\gamma-\mathrm{Al}_{2} \mathrm{O}_{3}$ and for single ozonation, respectively. Ozonation with $\gamma-\mathrm{Al}_{2} \mathrm{O}_{3}$ in presence of large amount of $\mathrm{NaCl}$ led to a first increase of the toxicity of the effluent (after
$1.5 \mathrm{~h}$ ) and then to a decrease of the toxicity below the initial toxicity (after $5 \mathrm{~h}$ ). $\gamma-\mathrm{Al}_{2} \mathrm{O}_{3}$ is therefore a good candidate for catalytic ozonation of refinery wastewater containing refractory $\mathrm{PAH}$ and should be better performing in lower salinity water as seawater. The large controversy observed in ozonation in water is because ozonation depends of a lot of parameters as $\mathrm{pH}$, presence of salts, nature of the catalysts, but also is effluent composition dependent.

\section{Acknowledgments}

The authors acknowledge the French National Agency for Research (ANR) for supporting this study through the convention ANR ECOTECH 2010 project PETZECO (1081C0230/ANR-10-ECOT011-03). Special thanks are addressed to Bruno Navarra for his help for the development of the ozonation pilot, to Eddy Petit (HPLCUV), Valérie Bonniol (Ionic chromatography) and Guillaume Cazals (LC-MS) for their precious help in by-products identification.

\section{References}

[1] M. Petala, V. Tsiridis, P. Samaras, A. Zouboulis, G.P. Sakellaropoulos, Desalination 239 (2009) 229-246.

[2] P. Pocostales, P. Alvarez, F.J. Beltran, Chem. Eng. J. 168 (2011) 1289-1295.

[3] B. Kasprzyk-Hordern, P. Andrzejewski, A. Dabrowska, K. Czaczyk, J. Nawrocki, Appl. Catal. B:Environ. 51 (2004) 51-66.

[4] F.J. Beltran, F.J. Rivas, R. Montero-de-Espinosa, Appl. Catal. B: Environ. 47 (2004) 101-109.

[5] J. Reungoat, J.S. Pic, M.H. Manero, H. Debellefontaine, Separ. Sci. Technol. 42 (2007) 1447-1463.

[6] T. Merle, J.S. Pic, M.H. Manero, S. Mathe, H. Debellefontaine, Catal. Today 151 (2010) 166-172

[7] J. Reungoat, J.S. Pic, M.H. Manero, H. Debellefontaine, Water Sci. Technol. 62 2010) 1076-1083.

[8] J. Nawrocki, B. Kassprzyk-Hordern, Appl. Catal. B: Environ. 99 (2010) 27-42.

[9] C. Cooper, R. Burch, Water Res. 33 (1999) 3689-3694.

[10] H. Fujita, J. Izumi, M. Sagehashi, T. Fujii, A. Sakoda, Water Res. 38 (2004) 166-172.

[11] Y. Dong, H. Yang, K. He, X. Wu, A. Zhang, Appl. Catal. B: Environ. 82 (2008) 163-168.

[12] T. Merle, J.S. Pic, M.H. Manéro, S. Mathé, H. Debellefontaine, Ozone-Sci. Eng. 32 (2010) 391-398

[13] J. Reungoat, J.S. Pic, M.H. Manéro, H. Debellefontaine, Water Sci. Technol. 62 (2010) 1076-1083.

[14] H. Valdés, S. Alejandro, C.A. Zaror, J. Hazard. Mater. 227 (2012) 34-40.

[15] L. Qi, H. You, Z. Zhang, C. Feng, S. van Agtmaal, Int. J. Electrochem. Sc. 8 (2013) 5457-5468.

[16] F. Qi, B. Xu, Z. Chen, L. Feng, L. Zhang, D. Sun, Chem. Eng. J. 219 (2013) 527-536.

[17] W. Aboussaoud, M.H. Manéro, J.S. Pic, H. Debellefontaine, Ozone: Sci. Eng (2014), accepted manuscript.

[18] J. Vittenet, J. Rodriguez, E. Petit, D. Cot, J. Mendret, A. Galarneau, S. Brosillon, Microporous Mesoporous Mater. 189 (2014) 200-209.

[19] H. Fujita, K. Shiraishi, T. Fujii, A. Sakoda, J. Izumi, Adsorption 11 (2005) 835-839.

[20] A. Ikhlaq, D.R. Brown, B. Kasprzyk-Hordern, Appl. Catal. B: Environ. 129 (2013) 437-449.

[21] N. Brodu, M.H. Manéro, C. Andriantsiferana, J.S. Pic, H. Valdés, Chem. Eng. J. 231 (2013) 281-286

[22] M. Ernst, F. Lurot, J.-C. Schrotter, Appl. Catal. B: Environ. 47 (2004) 15-25.

[23] T.Zhang, C. Li, J. Ma, H. Tian, Z. Qiang, Appl. Catal. B: Environ. 82 (2008) 131-137.

[24] F. Qi, Z. Chen, B. Xu, J. Shen, J. Ma, C. Joll, A. Heitz, Appl. Catal. B: Environ. 84 (2008) 684-690.

[25] US Environmental Protection Agency, Ambient Water Criteria for 2,4Dimethylphenol, Environmental Protection of Water Regulations and Standards Division, Washington, DC, 1990.

[26] J.P. Ghosh, K.E. Taylor, J.K. Bewtra, N. Biswas, Chemosphere 71 (2008) 1709-1717. 
[27] A. Galarneau, D. Desplantier, R. Dutartre, F. Di Renzo, Microporous Mesoporous Mater. 27 (1999) 297-308.

[28] J. Bergraser, J. Savignac, M. Jacob, P. Pedenaud, N. Lesage, IOA Proceedings, Berlin, 2013.

[29] M. Akia, S.M. Alavi, Z.F. Yan, Petrol. Coal 52 (2010) 208-289.

[30] M. Trapido, Y. Veressinina, R. Munter, J. Environ. 124 (1998) 690-694.

[31] L. Zhao, J. Ma, Z. Sun, Appl. Catal. B: Environ. 79 (2007) 244-253.

32] A. Kahru, L. Pollumaa, Oil Shale 23 (2006) 53-93.

33] E.B. Azevedo, F.R. de Aquino Neto, M. Dezotti, J. Hazard. Mater. 128 (2006) $182-191$.

[34] J.P. Scott, D.F. Ollis, Environ. Progr. 14 (2005) 88-103.

[35] F. Fourcade, S. Yahiat, K. Elandaloussi, S. Brosillon, A. Amrane, Chem. Eng. Technol. 35 (2012) 1-11.

[36] M. Gurol, P. Singer, Water Res. 3 (1983) 1173-1181.

[37] H. Sang-Kuk, I. Kazuhiro, H. Utsumi, Water Res. 32 (1998) 3261-3266.

38] T. Poznyak, R. Tapia, J. Vivero, I. Chairez, J. Mex. Chem. Soc. 50 (2006) 28-35.

[39] N.A.S. Amin, J. Akhtar, H.K. Rai, Chem. Eng. J. 158 (2010) 520-527.

40] Y. Lui, J. Shen, Z. Chen, L. Yang, Y. Han, Appl. Catal. A: Gen. 403 (2011) 112-118.

[41] E. Mvula, C. Von Sonntag, Org. Biomol. Chem. 1 (2003) 1749-1756.

[42] M.K. Ramseier, U.V. Gunten, Ozone-Sci. Eng. 31 (2009) 201-215.

[43] T.N. Das, J. Phys. Org. Chem. 22 (2009) 872-882.
[44] C.-R. Huang, H.-Y. Shu, J. Hazard. Mater. 41 (1995) 47-64.

45] Q. Liu, B. Shentu, C. Gu, J. Zhu, Z. Weng, Aiche J. 55 (2009) 2716-2724.

[46] J.B. Stothers, Carbon-13 NMR Spectroscopy, Academic Press, 1972.

[47] H.O. Kalinowsky, S. Berger, S. Braun, ${ }^{13}$ C NMR Spectroskopie, Georg Thieme Verlag, 1984

[48] K.M. Bulanin, J.C. Lavalley, A.A. Tsyganenko, J. Phys. Chem. 99 (1995) 10294-10298.

49] K.M. Bulanin, J.C. Lavalley, A.A. Tsyganenko, Coll. Surf. A: Phys. Eng. Aspects 101 (1995) 153-158.

[50] C.-H. Liao, S.-F. Kang, F.-A. Wu, Chemosphere 44 (2001) 1193-1200.

[51] L.R.B. Yeatts, H. Taube, J. Amer. Chem. Soc. 71 (1949) 4100-4105.

52] A.V. Levanov, I.V. Kuskov, E.E. Antipenko, V.V. Lunin, Russian J. Phys. Chem. A (2012) 757-762.

[53] Y.-J. Shih, K.-H. Chen, Y.-H. Huang, J. Taiwan Inst. Chem. Engineers 45 (2014) 962-966.

[54] E.B. Azevedo, F.R.D. Neto, M. Dezotti, J. Hazard. Mater. 128 (2006) 182-191.

[55] C. Rav-Acha, R. Blits, Water Res. 19 (1985) 1273-1281.

[56] J. Tillner, C. Hollard, C. Bach, C. Rosin, F.-F. Munoz, X. Dauchy, J. Chrom. A 1315 (2013) 36-46.

[57] K. Kosaka, H. Koshino, N. Yoshida, S. Kunikane, J. Water Supply Res. Technol.-Aqua 59 (2010) 41-52. 